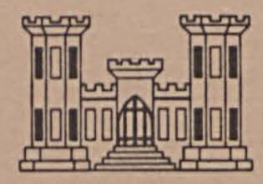

MISCELLANEOUS PAPER N-76-6

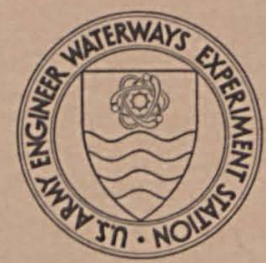

\title{
DELIBERATE ROAD CRATER DESIGN TEST SERIES: RAYSTOWN, PENNSYLVANIA
}

by

Howard H. Reed

Weapons Effects Laboratory

U. S. Army Engineer Waterways Experiment Station

P. O. Box 631, Vicksburg, Miss. 39180

May 1976

Final Report

Approved For Public Release; Distribution Unlimited

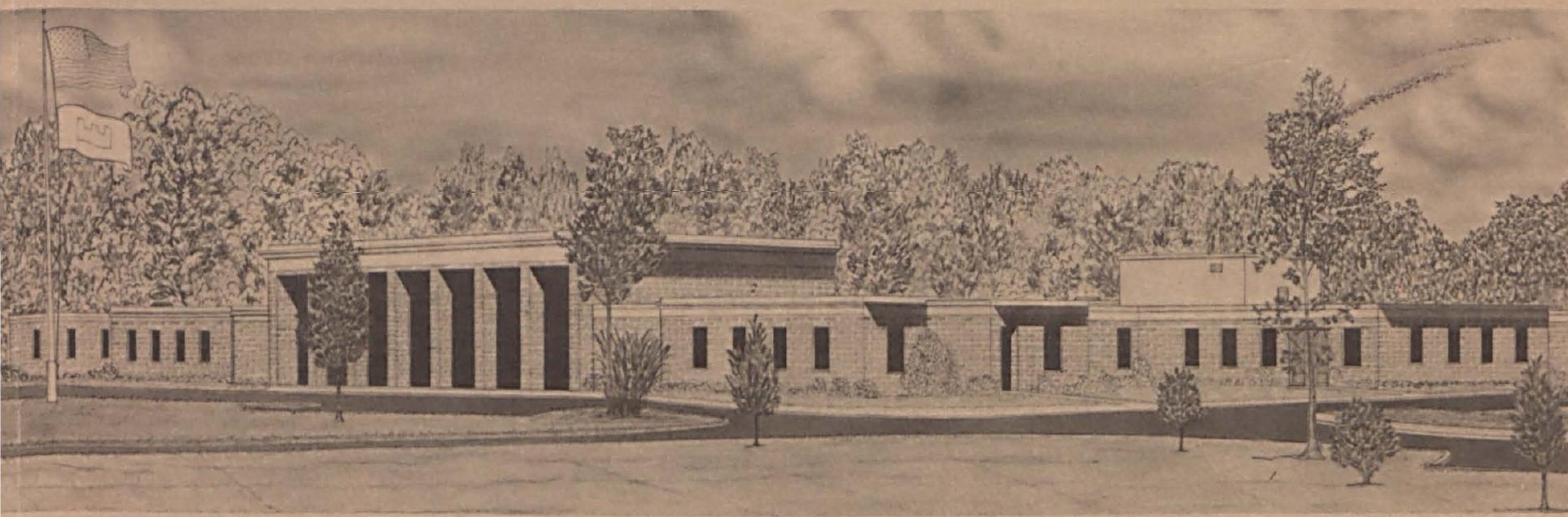

Prepared for Office, Chief of Engineers, U. S. Army

Washington, D. C. 20314

LUBRARY BRANCH

TECHNICAL INFORMATION CENTER

US ARMY ENGINEER WATERWAYS EXPERIMENT STAT

VICKSBURG, MISSISSIPPI 


\begin{tabular}{|c|c|}
\hline REPORT DOCUMENTATION PAGE & $\begin{array}{c}\text { READ INSTRUCTIONS } \\
\text { BEFORE COMPLETING FORM }\end{array}$ \\
\hline $\begin{array}{l}\text { 1. REPORT NUMBER } \\
\text { Miscellaneous Paper N-76-6 }\end{array}$ & 3. RECIPIENT'S CATALOG NUMBER \\
\hline \multirow{2}{*}{$\begin{array}{l}\text { 4. TITLE (and Subttilø) } \\
\text { DELIBERATE ROAD CRATER DESIGN TEST } \\
\text { SERIES: RAYSTOWN, PENNSYLVANIA }\end{array}$} & $\begin{array}{l}\text { 5. TYPE OF REPORT \& PERIOD COVERED } \\
\text { Final report }\end{array}$ \\
\hline & 6. PERFORMING ORG. REPORT NUMBER \\
\hline $\begin{array}{l}\text { 7. AUThOR(a) } \\
\text { Howard H. Reed }\end{array}$ & 8. CONTRACT OR GRANT NUMEER( () \\
\hline $\begin{array}{l}\text { 9. PERFORMING ORGAMIZATION NAME AND ADDRESS } \\
\text { U. S. Army Engineer Waterways Experiment Station } \\
\text { Weapons Effects Laboratory } \\
\text { P. O. Box 631, Vicksburg, Mississippi } 39180\end{array}$ & $\begin{array}{l}\text { 10. PROGRAM ELEMENT, PROJECT, TASK } \\
\text { AREA \& WORK UNIT NUMBERS }\end{array}$ \\
\hline \multirow{2}{*}{$\begin{array}{l}\text { 11. CONTROLLING OfFICE NAME AND ADDRESS } \\
\text { Office, Chief of Engineers, U. S. Army } \\
\text { Washington, D. C. } 20314\end{array}$} & $\begin{array}{l}\text { 12. REPORT DATE } \\
\text { May } 1976\end{array}$ \\
\hline & $\begin{array}{l}\text { 13. NUMBER OF PAGES } \\
38\end{array}$ \\
\hline \multirow[t]{2}{*}{ 14. MONITORING AGENCY NAME \& AODRESS(If dilforent from Controllind Offico) } & $\begin{array}{l}\text { 15. SECURITY CLASS. (of thie report) } \\
\text { Unclassified }\end{array}$ \\
\hline & $\begin{array}{l}\text { 15a. DECLASSIFICATION/DOWNGRADING } \\
\text { SCHEDULE }\end{array}$ \\
\hline
\end{tabular}

Approved for public release; distribution unlimited.

17. DISTRIBUTION STATEMENT (of tho abetract onterod In Block 20, If different from Ropott)

18. SUPPLEMENTARY NOTES

19. KEY WORDS (Continue on reverse alde If nocessery and ldentlfy by block number)

Cratering

Explosive charges

Road craters

Slurry explosive

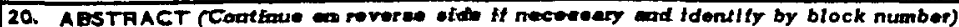

The Deliberate Road Crater Design Test Series, executed by the U. S. Army Engineer Waterways Experiment Station Explosive Excavation Research Laboratory in conjunction with elements of the 176th Engineer Group, Virginia National Guard, was conducted in May 1973 near the Raystown Reservoir project, Huntingdon, Pennsylvania. The tests consisted of several deliberate road cratering designs and a series of equalweight cratering comparisons. The two explosives involved were the U.S. Army $40-\mathrm{lb}(18.1-\mathrm{kg}) \mathrm{cratering}$ charge and a slurry explosive developed for Army consideration by Hercules, Inc. Test results demonstrated that the Hercules slurry performed as well as the standard cratering charges. The various designs used resulted in effective road craters. It was demonstrated that creating emplacement holes for the explosive is the most difficult operation in road cratering. 
THE CONTENTS OF THIS REPORT ARE NOT

TO BE USED FOR ADVERTISING, PUBLICATION, OR PROMOTIONAL PURPOSES. CITATION OF TRADE NAMES DOES NOT CONSTITUTE AN OFFICIAL ENDORSEMENT OR APPROVAL OF THE USE OF SUCH COMMERCIAL PRODUCTS. 


\section{PREFACE}

The project reported herein was conducted by the U. S. Army Engineer (USAE) Waterways Experiment Station (WES) Explosive Excavation Research Laboratory (EERL) from 14 to 31 May 1973. Prior to 21 April 1972 EERL was designated as the USAEWES Explosive Excavation Research Office and prior to 1 August 1971, as the USAE Nuclear Cratering Group.

This report is the final report on the Deliberate Road Crater Design Test Series. The purpose of this test series was to compare the cratering effectiveness of the U. S. Army's 40-lb cratering charge with a slurry specially designed for military use.

This work was funded by the Office, Chief of Engineers, U. S. Army, and the U. S. Army Materiel Command, Picatinny Arsenal, as part of the Military Engineering Applications of Commercial Explosives (MEACE) Program.

Project Raystown was accomplished successfully because of the combined efforts of many organizations and individuals, especially

176th Engineer Group (Combat), Richmond, Virginia, COL R. L. Vaughn, Commanding 479th Engineer Bn (C) (A), Watertown, New York, LTC R. E. Dunaway, Commanding 512th Engineer Bn (Maint), Cincinnati, Ohio, LTC R. M. Lockhart, Commanding 464th Engineer Bn (C) (A), Schenectady, New York, MAJ J. I. McKinney, Commanding Indiantown Gap Military Reservation, Annville, Pennsylvania, COL O. Henderson, Commanding

Mr. J. Weaver, Raystown Area Engineer, and his staff

Mr. J. Severini, Picatinny Arsenal, Dover, New Jersey

MAJ J. Briggs, CPT R. Gorski, and S4's T. Jangula, M. Zahn, and J. Morishita, all of EERL, who assisted in the tests and the preparation of this report

BG E. D. Peixotto, CE, and COL G. H. Hilt, CE, were Directors of WES during the conduct of the study and preparation of this report; Mr. F. R. Brown was Technical Director.

EERL Director and Deputy Director (Military) were LTC R. R. Mills, Jr., and MAJ R. H. Gates, respectively.

* Now designated the U. S. Army Materiel Development and Readiness Command. 


\section{CONTENTS}

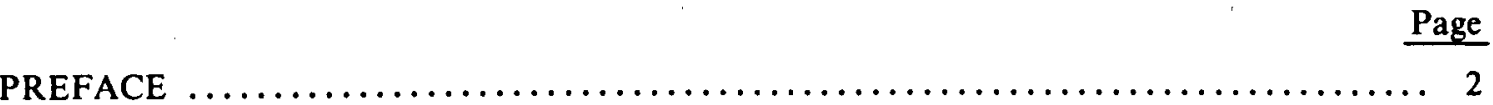

PART I: $\quad$ INTRODUCTION $\ldots \ldots \ldots \ldots \ldots \ldots \ldots \ldots \ldots \ldots \ldots \ldots \ldots \ldots \ldots \ldots \ldots \ldots \ldots$

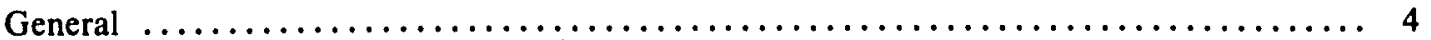

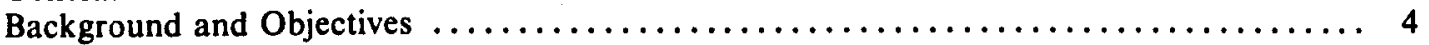

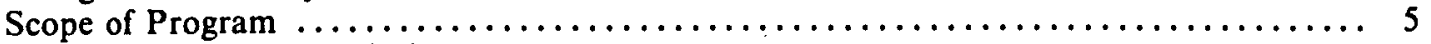

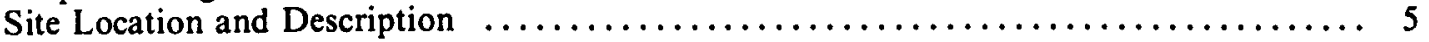

PART II: $\quad$ EXPERIMENTAL PROCEDURES $\ldots \ldots \ldots \ldots \ldots \ldots \ldots \ldots \ldots \ldots \ldots$

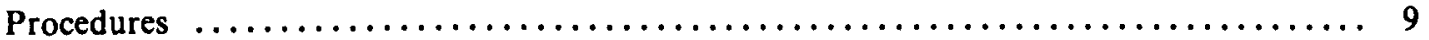

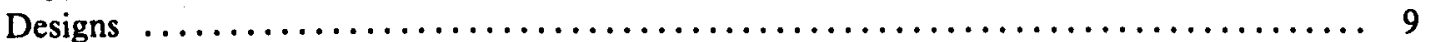

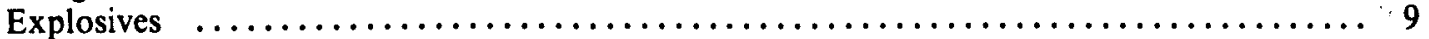

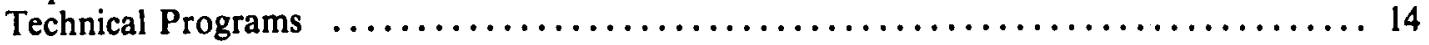

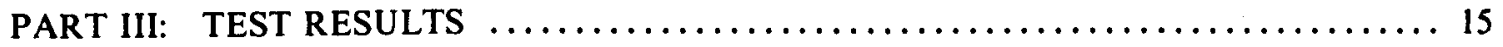

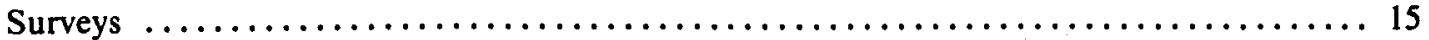

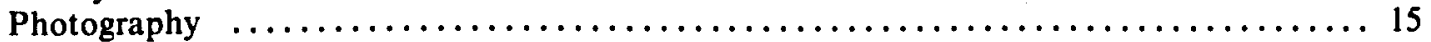

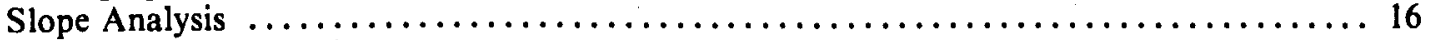

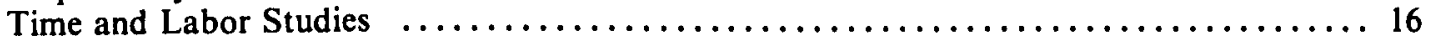

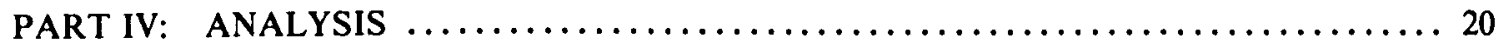

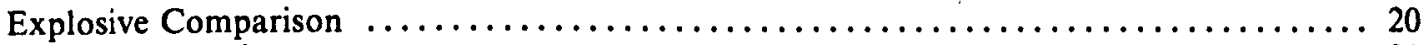

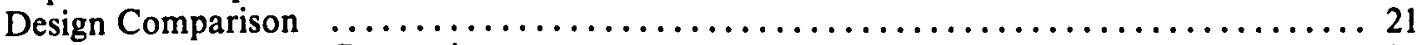

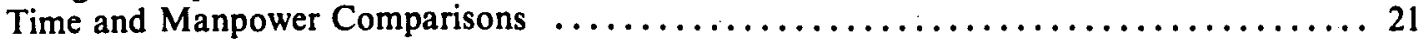

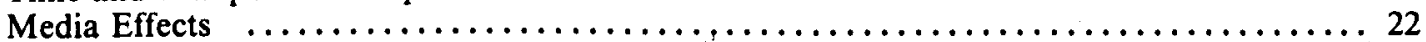

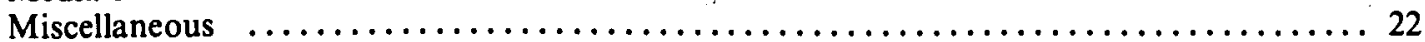

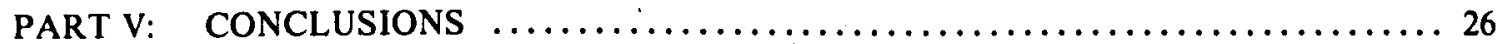

APPENDIX A: EMPLACEMENT HOLE OPERATIONS $\ldots \ldots \ldots \ldots \ldots \ldots \ldots \ldots \ldots$ Al

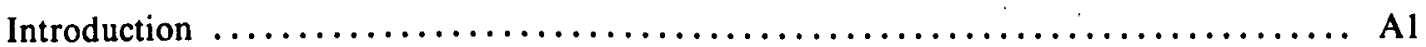

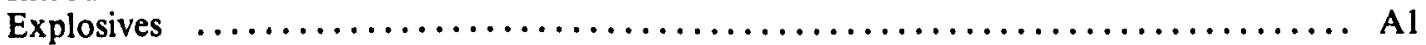

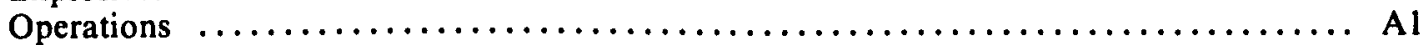

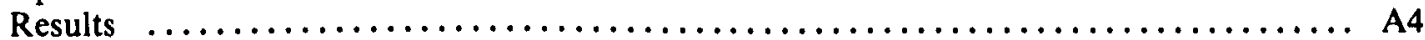

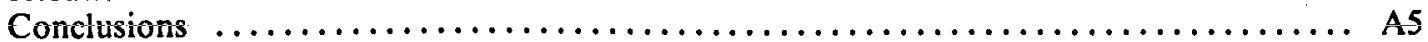

TABLE Al

APPENDIX B: SELECTED CRATER PROFILES $\ldots \ldots \ldots \ldots \ldots \ldots \ldots \ldots \ldots \ldots \ldots$

APPENDIX $\mathrm{C}: \quad$ RELIEVED-FACE CRATERS $\ldots \ldots \ldots \ldots \ldots \ldots \ldots \ldots \ldots \ldots \ldots \ldots \ldots$

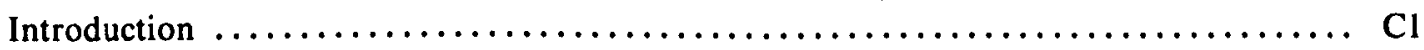

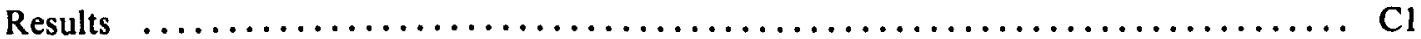

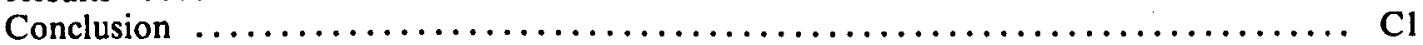




\title{
DELIBERATE ROAD CRATER DESIGN TEST SERIES: RAYSTOWN, PENNSYLVANIA
}

\section{PART I: INTRODUCTION}

\author{
GENERAL
}

1. The results of a series of cratering experiments conducted as part of the Military Engineering Applications of Commercial Explosives (MEACE) Program are summarized herein. The program consisted of deliberate road crater (DRC) experiments which tested various DRC designs and also compared the cratering effectiveness of the U. S. Army $40-\mathrm{lb}(18.1-\mathrm{kg})$ cratering charge with that of an aluminized ammonium-nitrate slurry developed for the consideration of Picatinny Arsenal. The tests were conducted at the U. S. Army Corps of Engineers Raystown Reservoir project in Huntingdon County, Pennsylvania. The experiments were conducted from 14 to 31 May 1973 by elements of the 176th Engineer Group, Virginia National Guard, as part of their annual training exercise, under the technical supervision of the U.S. Army Engineer Waterways Experiment Station Explosive Excavation Research Laboratory.

\section{BACKGROUND AND OBJECTIVES}

2. The objective of the MEACE Program is to develop engineering criteria and employment procedures for the design and execution of excavation and target-destruction combat engineering missions using commercial bulk explosives. Under the MEACE Program, Project Armor Obstacle II (AOII) was conducted to compare the cratering performance of a commercial slurry explosive and the standard 40-lb (18.1-kg) cratering charge, and to evaluate the obstacle-effectiveness of the resulting craters. Several different DRC designs were tested during AOII.*

3. Concurrent with Project AOII, Picatinny Arsenal of the U. S. Army Materiel Command was contracting Hercules, Inc., for a study to determine the feasibility of a portable mixing and pumping unit to produce a slurry explosive. A specific goal of this study was to select a family of slurry explosives that would exceed from 1.5 to 2.5 times the effectiveness of ANFO in cratering performance. This requirement was later modified to slurries 1.5 to 2.5 times as energetic as ANFO as measured by the underwater energy test. **

4. The actual execution of this test series was prompted when the 176th Engineer Group, Virginia National Guard, conducted realistic field training at the Raystown Reservoir project. The 176th Group agreed to allow Explosive Excavation Research Laboratory (EERL) to plan and conduct a DRC program using EERL-furnished designs and explosives. The Raystown test series evolved from the road cratering portion of Project AOII and the Picatinny slurry-system study.

* J. Briggs, “Project Armor Obstacle 11," Miscellaneous Paper E-73-4, Oct 1973, Explosive Excavation Research Laboratory, U. S. Army Engineer Waterways Experiment Station, CE, Livermore, Calif.

** D. A. Wedwick, "Experimental Study to Determine Feasibility of a Portable Mixing and Pumping Unit to Produce Slurry Explosive," Final Report, 1972, Hercules Inc., Kenvil, N. J. 
5. The objectives of the DRC Design Test Series were to:

$a$. Compare the cratering effectiveness, as measured by total volume of material excavated, of standard 40-lb $(18.1-\mathrm{kg})$ ammonium-nitrate canisters with the effectiveness of a slurry specially designed for military consideration.

b. Compare, under simulated tactical conditions, the time and manpower required to execute various DRC designs.

6. Inherent in these objectives were several subtasks such as:

a. Comparison of the effectiveness of the various DRC designs.

$b$. Evaluation of the $40-\mathrm{lb}(18.1-\mathrm{kg})$ shaped charge and pioneer tool sets in digging emplacement holes.

c. Evaluation of the effects of different soil conditions on cratering performance and the excavation of emplacement holes.

$d$. Observation of the effectiveness of auxiliary demolition equipment.

$e$. Determination of the maximum range of missile throw.

7. Project Raystown presented not only the opportunity for further field testing of DRC designs and a potential military slurry, but it also allowed observation of actual emplacement times and provided exposure to typical problems encountered by engineer troops.

\section{SCOPE OF PROGRAM}

8. The program consisted of 24 DRC detonations, three shots each of eight different charge designs. The designs and explosives used in each detonation are given in Table 1. Design $A^{*}$ is considered the standard of reference for the program.

9. The cratering missions were executed under simulated tactical conditions by personnel of the 176th Engineer Group over a period of 3 weeks, with a new battalion operating in the area each week. Normally, a company was given a separate road cratering mission. The company commander normally assigned the mission to a platoon, which executed the task with its own organic equipment. EERL personnel provided technical supervision of each operation.

10. Several technical programs were conducted, primarily crater measurements, documentary photography, and missile observations. The results of these programs are discussed in Part III.

\section{SITE LOCATION AND DESCRIPTION}

11. The roads selected for cratering were situated below the high-water line of the Raystown Reservoir, which is located in the Ridge and Valley province of Pennsylvania, about 20 miles (32 km) east of Altoona (Figure 1). The dam is on the Raystown Branch of the Juniata River, a tributary of the Susquehanna River. Steep hillsides and mountain slopes surround the lake. During the test period, and for some 2 to 3 weeks prior, the area was subjected to extremely rainy weather, causing the reservoir to fill much more rapidly than anticipated.

\footnotetext{
* Office, Chief of Engineers, Department of the Army, "Explosives and Demolitions," Field Manual FM 5-25, Feb 1971, Washington, D. C.
} 


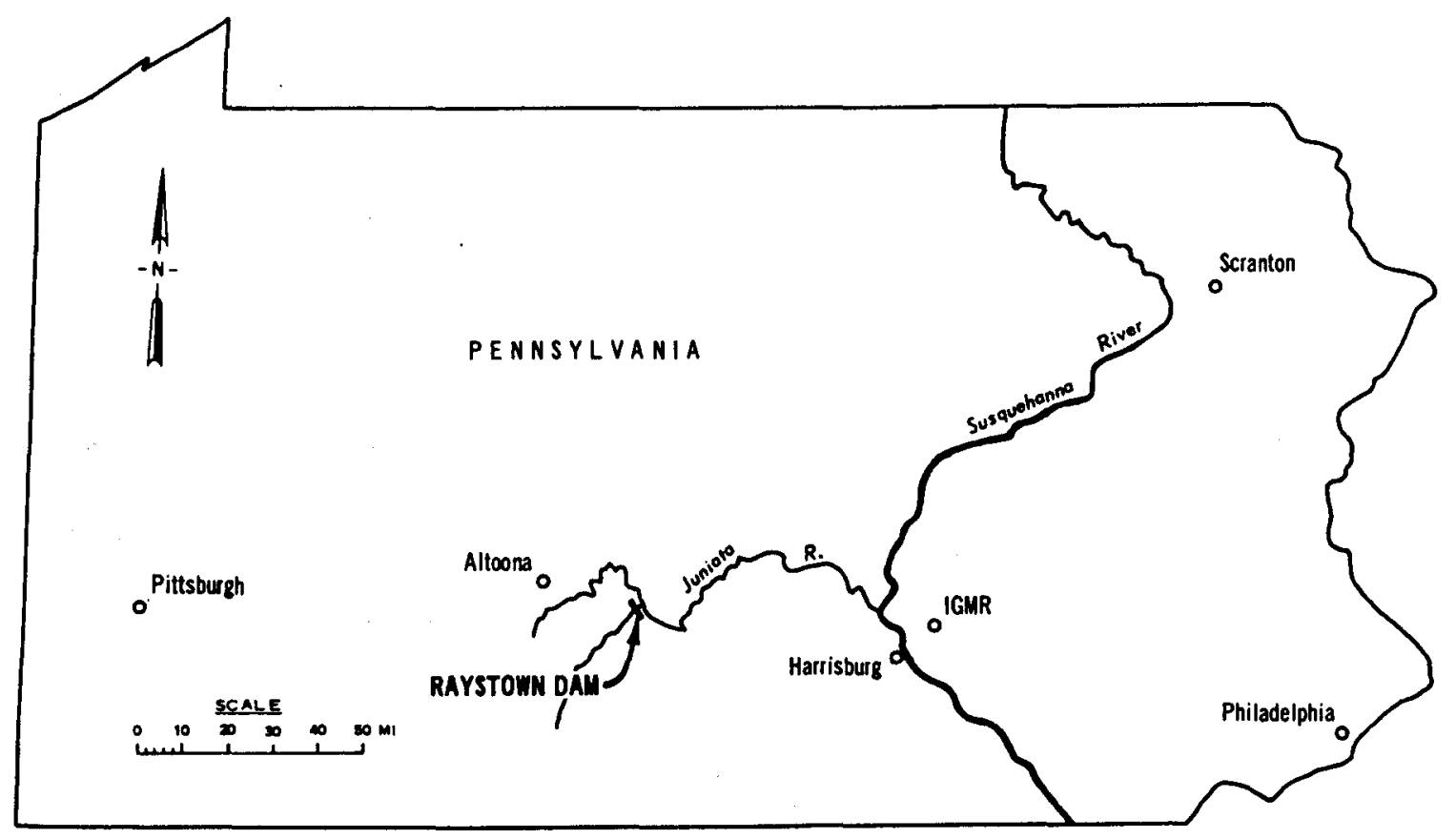

Figure 1. Site location

12. Soils in the area are shale derivatives. The cratering was conducted at three separate and somewhat distinct road sites. Generally, the soils encountered at all three sites are yellow, orange, and red soils with water contents of from 12 to 17 percent. Gradation curves indicate that the soils are sandy clays and silts.

13. Site I was a light-duty all-weather road that ran down to the river. It appeared to have been constructed using a sandstone and clay base course topped with a waterproofing of asphalt. The majority of the asphalt had eroded away leaving a well compacted surface. The subgrade material was natural, in-place soil. Depending on the location on the road, the subgrade varied from orange and yellow clayey silt to a denser, red sandy clay, and occasionally was a compact, weak, red sandstone. In most instances, this material had 2 -in. to $1-\mathrm{ft}(5-$ to $30-\mathrm{cm})$ sandstone cobbles dispersed in it. Several areas had large amounts of big cobbles, indicating the possibility that river-run material had been brought to the site during construction.

14. Site II was adjacent to site I, but instead of running down to the water, the road paralleled the river along a wide and gently sloping valley. This road could be best described as a light-duty dirt road, the surface and drainage structures of which had been destroyed during clearing operations conducted as part of the dam project (Figure 2). Materials in this area consisted of dense, red sandy clays and silts with a few sandstone fragments; very few sandstone cobbles were present. Because of the narrowness of this road and the high uphill bank, the craters were aligned with their long axis parallel to the roadway.

15. Site III was a medium-duty all-weather road and its construction was the best of all roads used for the tests (Figure 3). Much of the road was fill emplaced as the approach to a bridge. The fill consisted of compacted river-run material containing many sandstone cobbles of various sizes, topped with a 4-in. $(10-\mathrm{cm})$ lift of approximately 4-in. $(10-\mathrm{cm})$ minus, crushed, angular base course which appeared to be a fine-grained, dark-gray limestone. This was in turn surfaced with a 2 -in. $(5-\mathrm{cm})$ layer of asphalt. This road was in very good condition. 


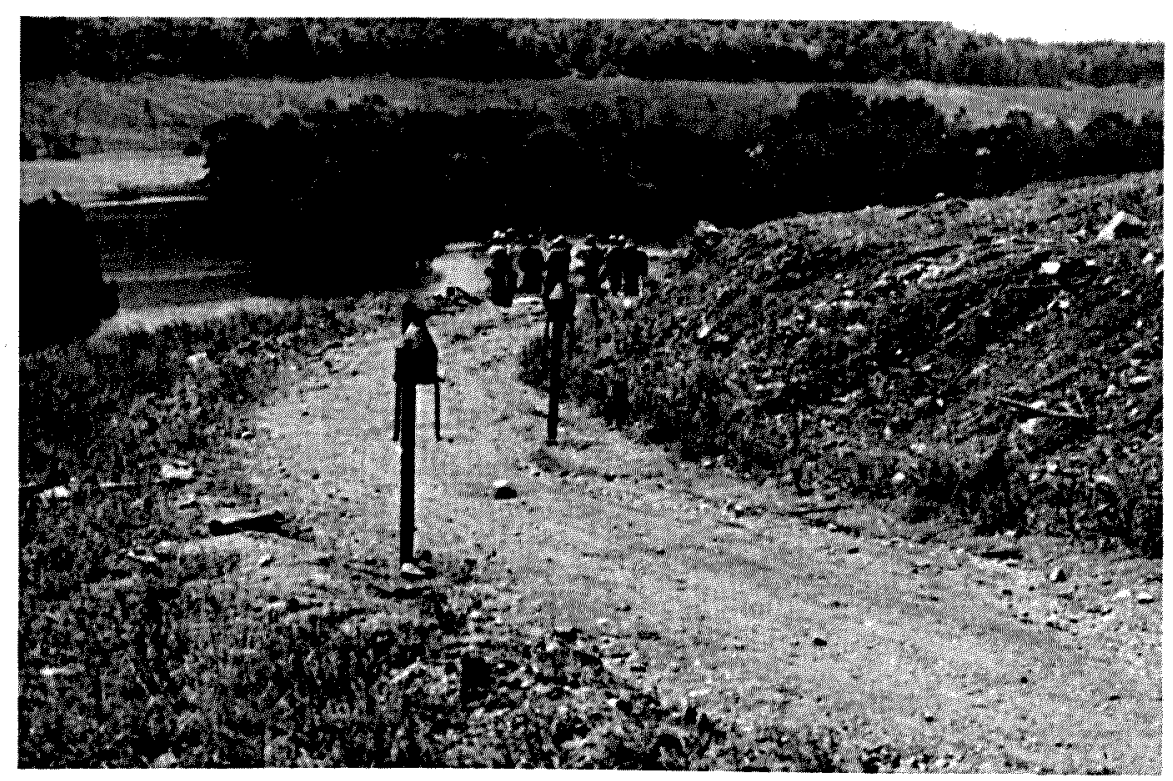

Figure 2. Site /I roadway

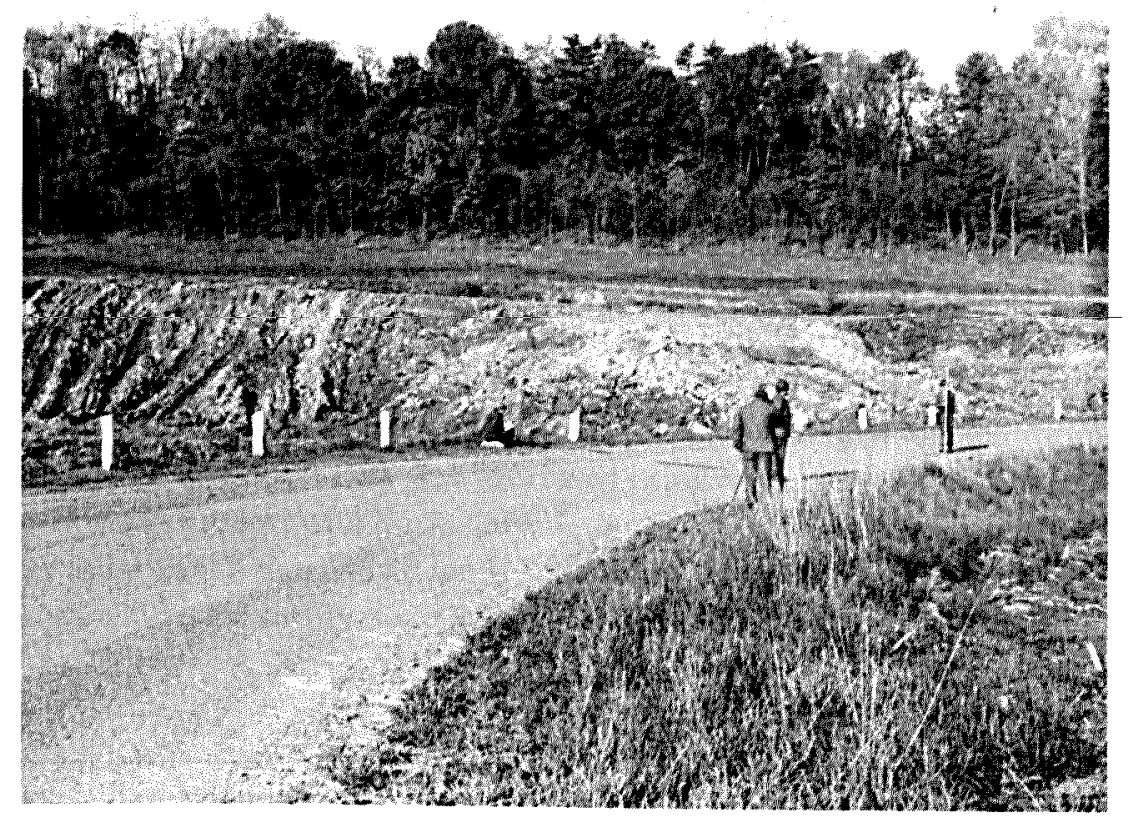

Figure 3. Site III roadway 
Table 1

Deliberate Road Crater Designs

\begin{tabular}{|c|c|c|c|c|c|c|c|c|c|}
\hline \multirow[b]{2}{*}{ Design } & \multirow{2}{*}{$\begin{array}{l}\text { Number } \\
\text { of Holes }\end{array}$} & \multicolumn{2}{|c|}{ Depth* } & \multicolumn{2}{|c|}{ Spacing } & \multirow{2}{*}{$\begin{array}{c}\begin{array}{c}\text { Type of } \\
\text { Explosive }\end{array} \\
\end{array}$} & \multicolumn{2}{|c|}{$\begin{array}{c}\text { Amount/ } \\
\text { Hole }\end{array}$} & \multirow[b]{2}{*}{ Remarks } \\
\hline & & ft & $\overline{\mathbf{m}}$ & ft & $\underline{\mathbf{m}}$ & & $\underline{\text { Ib }}$ & $\mathbf{k g}$ & \\
\hline A & 5 & $\begin{array}{l}7 \text { ( } 3 \text { each) } \\
5 \text { ( } 2 \text { each) }\end{array}$ & $\begin{array}{l}2.13 \\
1.52\end{array}$ & 5 & 1.52 & AN & $\begin{array}{l}80 \\
40\end{array}$ & $\begin{array}{l}36.3 \\
18.1\end{array}$ & $\begin{array}{l}\text { Standard FM } \\
\text { 5-25 design }\end{array}$ \\
\hline B & 5 & $\begin{array}{l}7 \text { ( } 3 \text { each) } \\
5 \text { ( } 2 \text { each) }\end{array}$ & $\begin{array}{l}2.13 \\
1.52\end{array}$ & 5 & 1.52 & Slurry & $\begin{array}{l}80 \\
40\end{array}$ & $\begin{array}{l}36.3 \\
18.1\end{array}$ & \\
\hline $\mathrm{C}$ & 3 & 7 & 2.13 & 10 & 3.05 & AN & 120 & 54.4 & \\
\hline $\mathrm{D}$ & 3 & 7 & 2.13 & 10 & 3.05 & Slurry & 120 & 54.4 & \\
\hline $\mathrm{E}$ & 3 & 7 & 2.13 & 8 & 2.44 & AN & 80 & 36.3 & \\
\hline F & 3 & 7 & 2.13 & 8 & 2.44 & Slurry & 80 & 36.3 & \\
\hline G & 3 & 7 & 2.13 & 10 & 3.05 & Slurry & 120 & 54.4 & Inclined holes \\
\hline $\mathbf{H}$ & 7 & $\begin{array}{l}7 \text { (4 each) } \\
5 \text { (3 each) }\end{array}$ & $\begin{array}{l}2.13 \\
1.52\end{array}$ & 8 & 2.44 & Slurry & $\begin{array}{l}80 \\
60\end{array}$ & $\begin{array}{l}36.3 \\
27.2\end{array}$ & $\begin{array}{c}\text { Relieved-face crater, } \\
8 \text {-ft }(2.44-\mathrm{m}) \text { spac- } \\
\text { ing between rows }\end{array}$ \\
\hline
\end{tabular}

* Diameter of hole at listed depth was at least 7 in. $(17.8 \mathrm{~cm})$. All holes were stemmed after emplacing explosives.

** AN is the standard $40-\mathrm{lb}(18.1-\mathrm{kg})$ ammonium-nitrate canister. The slurry was provided in $40-\mathrm{lb}(18.1-\mathrm{kg})$ bags and poured into emplacement holes. 


\section{PART II: EXPERIMENTAL PROCEDURES}

\section{PROCEDURES}

16. The procedures followed in executing a DRC mission were quite simple. The Army's M3Al 40lb (18.1-kg) shaped charge (Lot No. JA 1-5, Loaded 5-63) was used to make the initial emplacement holes. The holes were excavated to final depth, or as close to final depth as possible, with a posthole digger. A posthole auger was used for holes deeper than $5 \mathrm{ft}(1.5 \mathrm{~m})$. Appen$\operatorname{dix} A$ details emplacement-hole construction operations.

17. The $40-\mathrm{lb}(18.1-\mathrm{kg})$ cratering charges were primed with detonating cord and lowered into the holes with rope. The bags of slurry were slit and the slurry was dumped into the hole. Boosters for the slurry were made by cutting a $2-1 / 2-\mathrm{lb}(1.13-\mathrm{kg})$ block of $\mathrm{C}-4$ in half and tying the two halves together around a double overhand knot of detonating cord (Figure 4). Each cratering canister was primed individually, whereas the booster for the slurry was placed between the last two bags loaded. If only one bag was loaded, the booster was placed on top of it. Holes were completely stemmed using excavated material; a detonating cord ring-main with an electric cap was used for all firings.

18. The operations were usually conducted by a platoon-size unit. The platoon leader directed the mission. The techniques varied greatly because of differing levels of training among the various platoons. Each platoon used its own organic equipment and demolition sets.

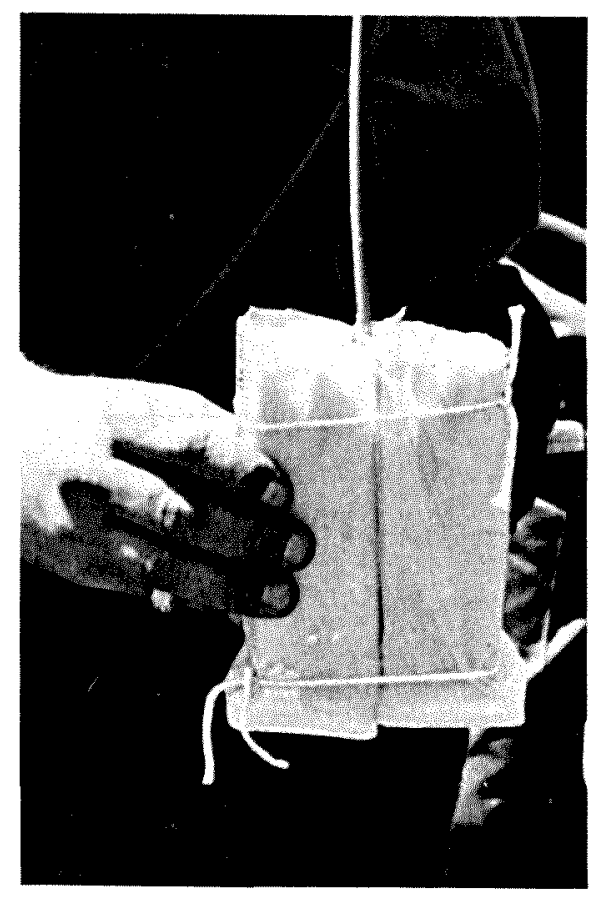

Figure 4. C-4 booster with detonator cord primer prior to loading downhole

\section{DESIGNS}

19. A total of five charge configurations were tested. Designs A and B were the Army's standard DRC design and were executed using the 40-lb $(18.1-\mathrm{kg})$ cratering charge and the slurry, respectively. Designs $\mathrm{C}$ through $\mathrm{F}$ used a three-hole design based on previous testing conducted during Project AOII in Montana in the fall of 1972.* They were executed using both the canister charge and the slurry. Designs $\mathrm{G}$ and $\mathrm{H}$ were executed with slurry only; design $\mathrm{G}$ is a modification of a technique used by the Canadian Army using slant holes, and design $H$ is the Army's relieved-face crater design. ${ }^{* *}$ The designs for the DRC's are illustrated in Figures 5-9.

\section{EXPLOSIVES}

20. The two cratering explosives used in these tests were the Army's 40-lb (18.1-kg) block

\footnotetext{
Briggs, op. cit.

** Office, Chief of Engineers, op. cit.
} 


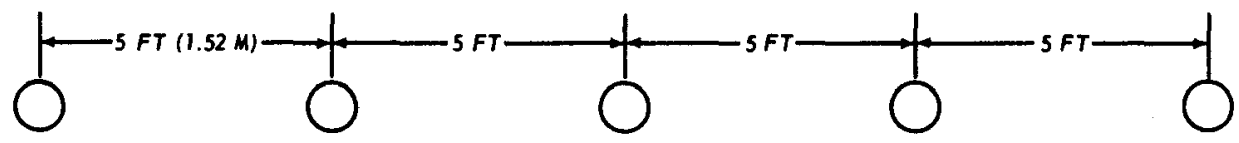

PLAN

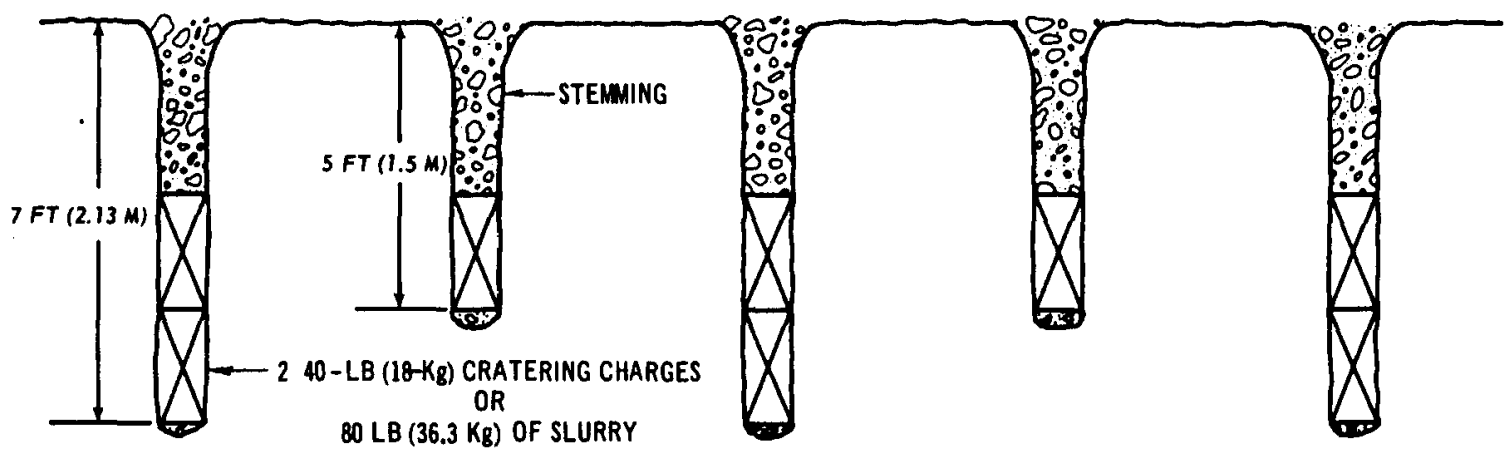

CROSS SECTION

Figure 5. Designs A and B charge configuration
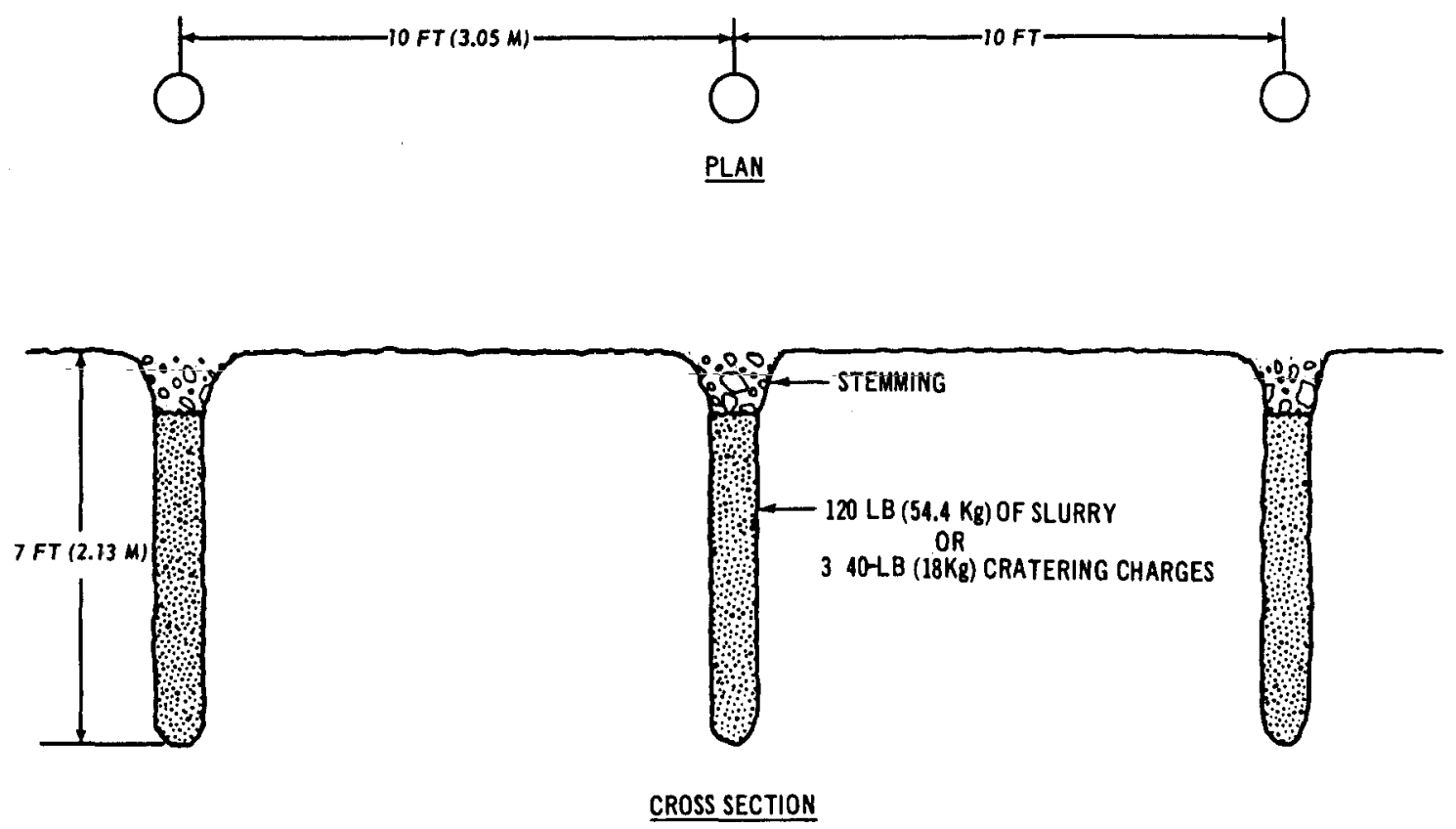

Figure 6. Designs $C$ and $D$ charge configuration 

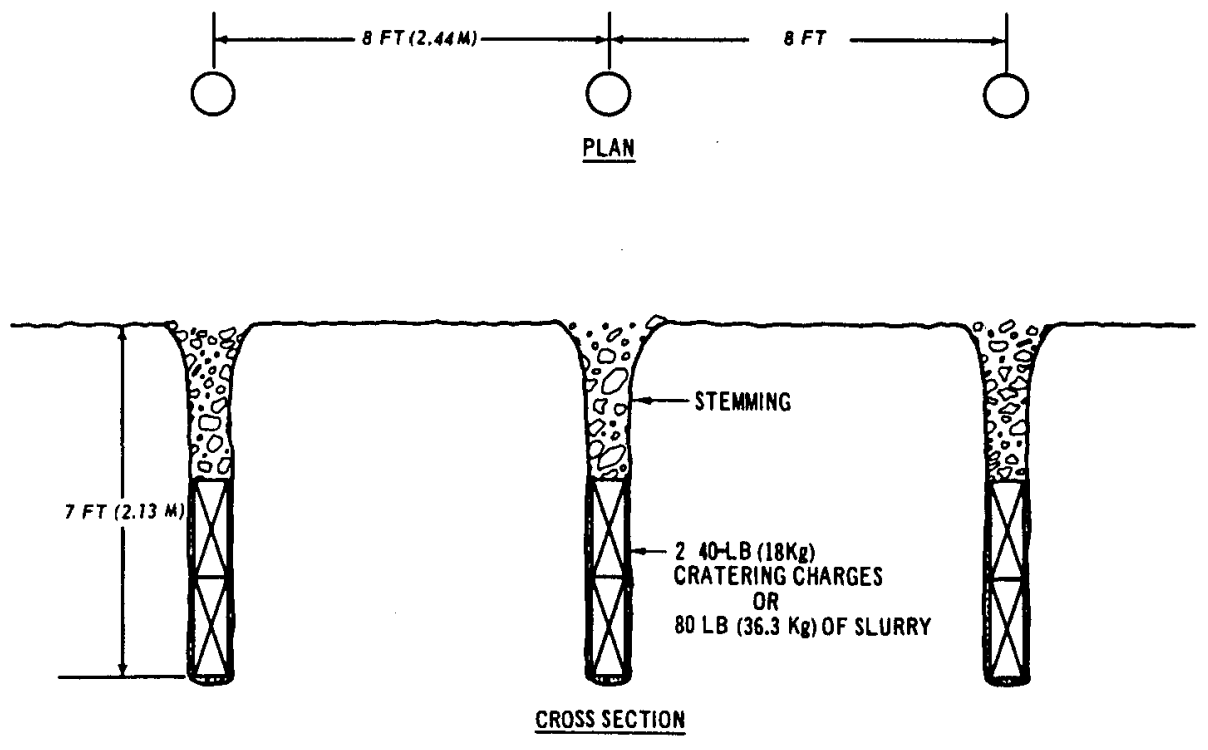

Figure 7. Designs $E$ and $F$ charge configuration
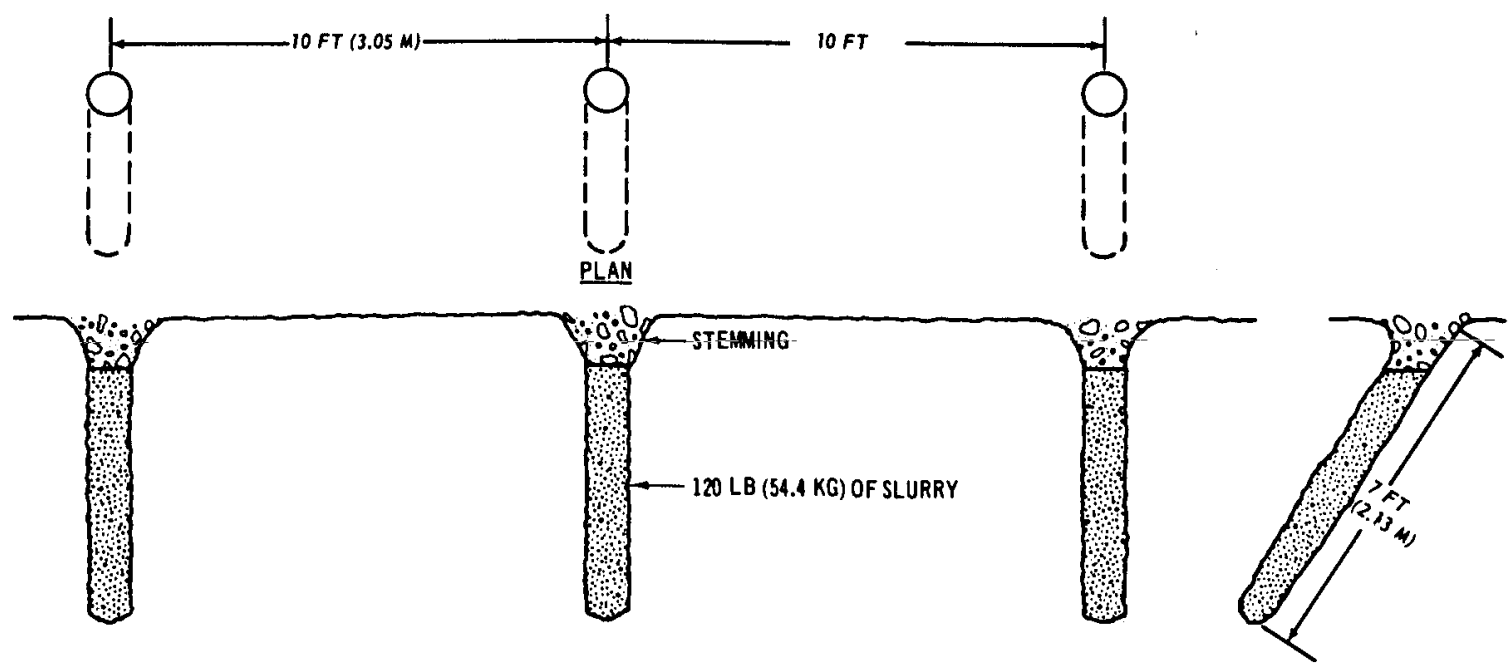

CROSS SECTION

END VIEW

Figure 8. Design G charge configuration 

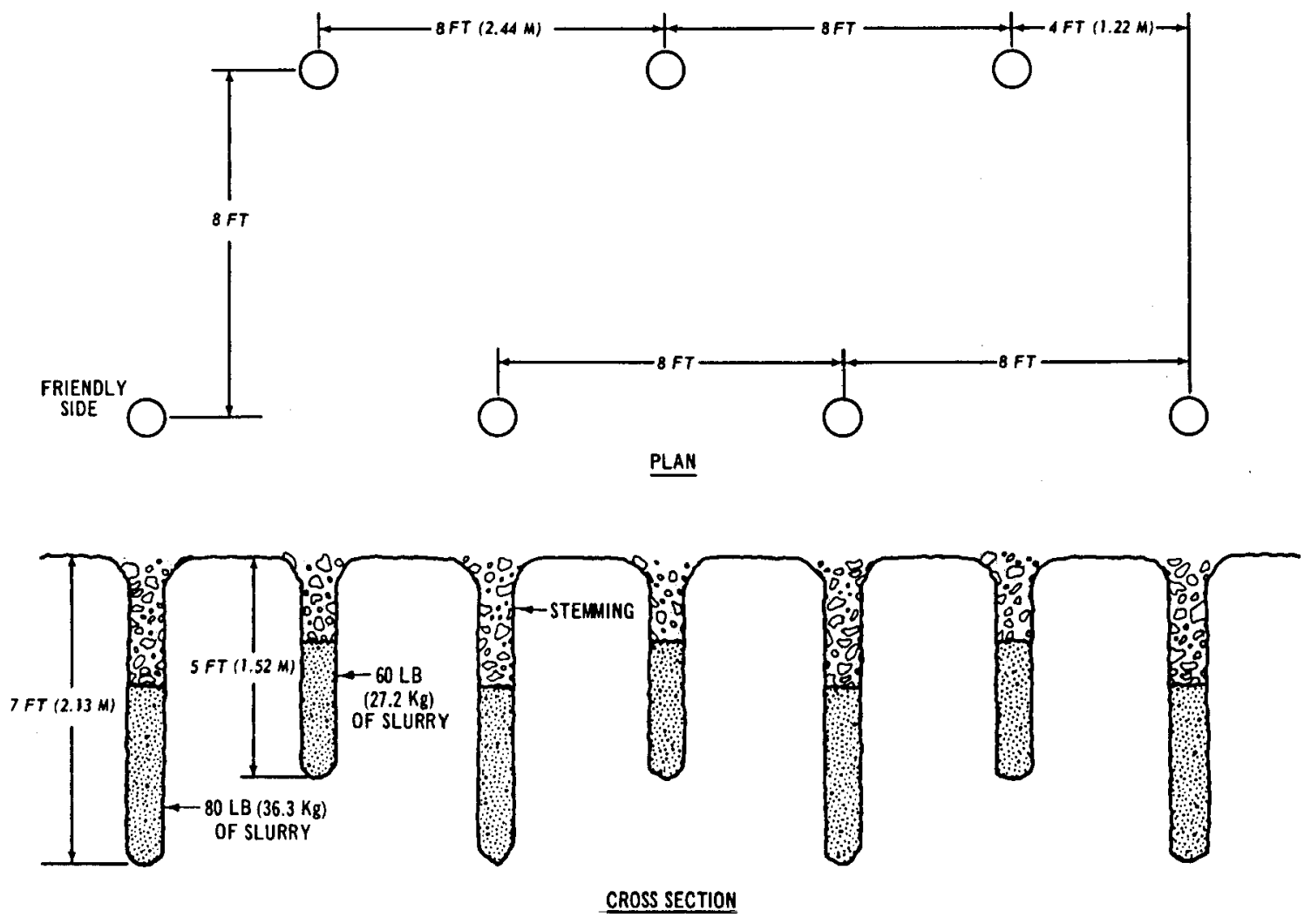

Figure 9. Design H charge configuration 
ammonium nitrate cratering charge* and an aluminized slurry developed for the Picatinny Arsenal by Hercules, Inc., designated Type C.**

21. The military cratering charge is a watertight, cylindrical metal container 7 in. $(17.8 \mathrm{~cm})$ in diameter and $24 \mathrm{in} .(61.0 \mathrm{~cm})$ high with approximately $30 \mathrm{lb}(13.6 \mathrm{~kg})$ of an ammonium nitrate-based explosive and a TNT-based explosive booster of approximately $10 \mathrm{lb}(4.5 \mathrm{~kg})$. Two priming tunnels are provided on the side for either a blasting cap or knotted detonation cord, and there is a metal ring on the top for loading.* The cratering charge's ammonium nitrate-based explosive was modified in 1968 by adding an appreciable amount of aluminum to increase energy output. The charges used on this project were loaded in July 1968 (Lot No. DUP-4-9).

22. The aluminized slurry consisted of a mixture of ammonium nitrate, calcium nitrate, water, and ethylene glycol mononitrate, with 28 percent by weight of aluminum added. Sensitivity was maintained by adding microballoons ( 4 percent) and the product was gelled and cross-linked.* The slurry was delivered in polyethylene bags each containing $40 \mathrm{lb}(18.1 \mathrm{~kg})$ and having a diameter of $8 \mathrm{in} .(20.3 \mathrm{~cm})$ and a length of $19 \mathrm{in} .(48.3 \mathrm{~cm})$. The slurry had a tough, pudding-like consistency and was water resistant whether inside or outside the protective bags (Figure 10).

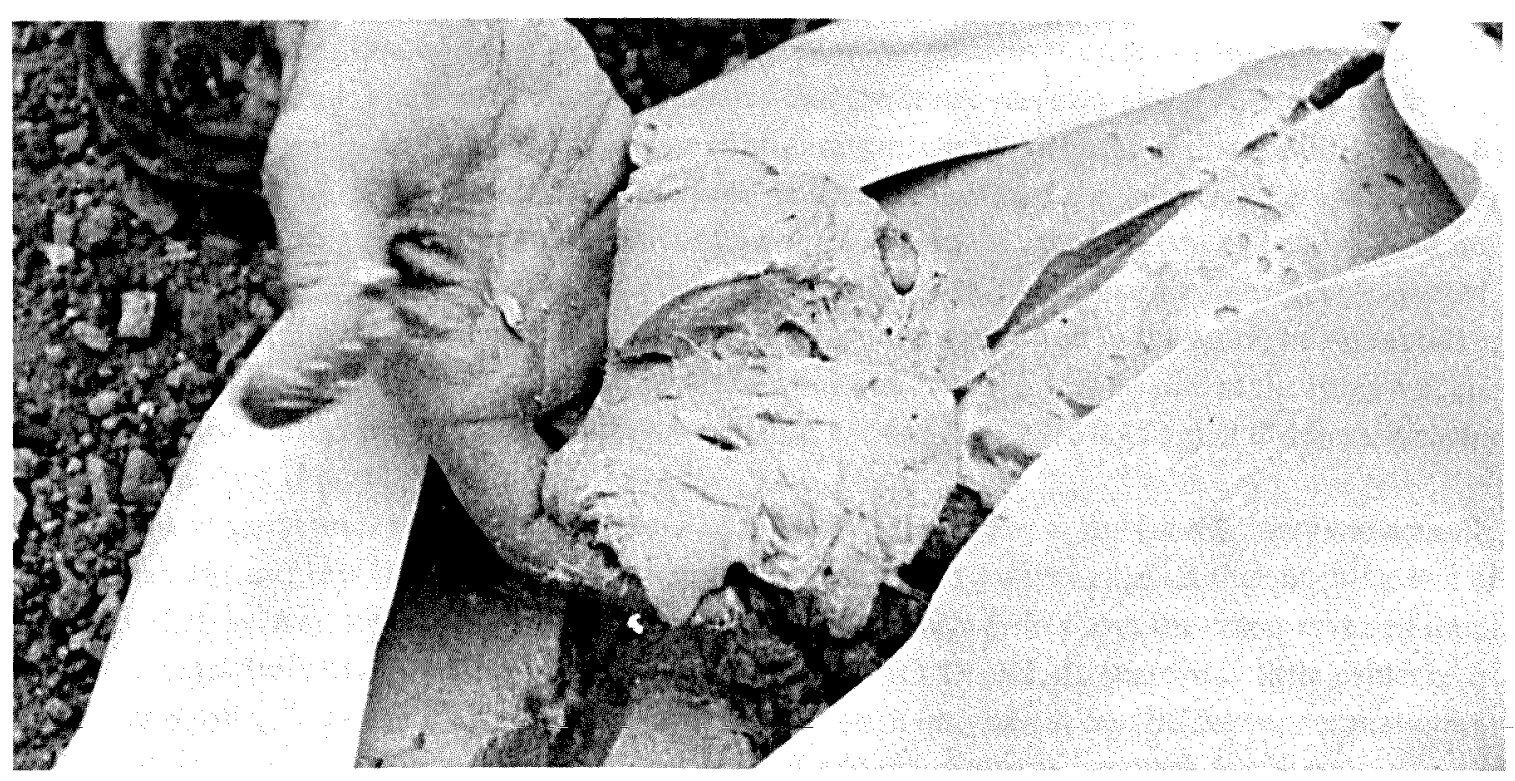

Figure 10. Slurry (note pudding-like consistency)

23. The known explosive properties of the two materials are shown below.

\begin{tabular}{lcc} 
& $\begin{array}{c}\text { Cratering } \\
\text { Charge }\end{array}$ & $\begin{array}{c}\text { Type C } \\
\text { Hercules Slurry }\end{array}$ \\
\cline { 2 - 2 } Density, gr/cc & 1.2 & 1.25 \\
Detonation velocity, m/sec & 3400 & 4150 \\
Estimated energy, cal $/ \mathrm{gr}$ & $1200-1800$ & 1650
\end{tabular}

* Office, Chief of Engineers, op. cit.

** Wedwick, op. cit. 


\section{TECHNICAL PROGRAMS}

24. The technical programs conducted during the Raystown project consisted of surveys, technical and documentary photography, and technical and operational data collected by test personnel. Pre-and postshot surveys were made with conventional techniques by teams from the participating battalions with EERL personnel assisting. Major phases of the program were documented by still photography and movies, and detonations were recorded using a standard-speed $16 \mathrm{~mm}$ motion-picture camera. Test personnel recorded site descriptions, ejecta throws, time and motion studies, weather conditions, soil conditions, and other significant aspects of each test. 


\section{PART III: TEST RESULTS}

\section{SURVEYS}

25. Crater dimensions were obtained from plots of conventional surveys. Volumes of the craters were determined from cross-sectional areas measured with a planimeter and a program which computes the volume of the end sections of each crater. Crater dimensions are given in Tables 2 and 3; representative crater sections are included in Appendix B.

\section{PHOTOGRAPHY}

26. The $16 \mathrm{~mm}$ high-speed motion-picture photography of each detonation was an excellent means of verifying field observations and analyzing problems that may have occurred in some of the detonations. Tabulation of photographic results is neither practicable nor possible, but the problems revealed by the movies are included in this section.

27. Postshot inspection of design $B 1$ indicated the possibility that the charges on either end of the row did not detonate. Quantities of unexploded slurry were found in the area of the holes and in the ejecta around each end. The postshot survey revealed that the crater was only about 60 percent as long as that produced by design $\mathrm{Al}$ which had the same configuration, charge size, and media conditions. These observations were verified by the motion pictures which revealed that the initiating detonating cord ring-main fired, setting off the downhole lines of detonating cord, but that the two end charges did not detonate. Photography did not reveal whether the booster in each of these two charges detonated; however, no unexploded booster or downline detonating cord was found in the crater or surrounding area. Based on this evidence, and the fact that this shot was only the second one of the program, the booster size for the remaining shots was increased from $1 / 2$ to $1 \mathrm{lb}(0.23$ to $0.45 \mathrm{~kg})$ of C-4 to the booster discussed in Part II.

28. Motion pictures verified that for most of the slurry shots fired at site I some slurry was actually burning in the air; this had been observed in the field, and the movies verified that burning bits of explosive had been ejected from the crater. Inspection of the ejecta field about the crater revealed small white particles (aluminum oxide) around the crater. At sites II and III there was little evidence of explosive burning in the air; this was unexplainable,-although only -about one-half of the-detonations at these two sites were photographed due to the lack of suitable protected camera locations.

29. In many of the detonation sequences, the camera location and field of view made observations of the ejecta from the detonations possible. These movies revealed that even the smaller detonations can throw ejecta considerable distances. This condition appeared to be especially true where the soil contained cobbles or large clumps of cohesive material; in some instances, these were ejected from 600 to $800 \mathrm{ft}$ ( 180 to $250 \mathrm{~m})$.

30. The last area in which photography was used to analyze probable problems was with design $\mathbf{H}$, the relieved-face crater. This design called for the addition of a second row of charges (parallel to a conventional DRC row) to be detonated $1 / 2$ to $1-1 / 2 \mathrm{sec}$ after the detonation of the first row. The charges in design $\mathrm{H} 1$ appeared to detonate fully, although the resulting slide slopes and size of the crater were not as steep and large, respectively, as expected. The other two shots obviously failed to detonate completely, one because of a faulty firing line and one because of an apparently faulty delay cap. Photographic analysis revealed that the first shot (design $\mathrm{HI}$ ) also failed to detonate properly. It was 
clearly evident that the ring-main used to initiate the second row of charges actually detonated in the air after it had been torn away from its down lines by the material ejected from the detonation of the first row. This design and the problems encountered are discussed in greater detail in Appendix $\mathrm{C}$.

\section{SLOPE ANALYSIS}

31. While no mobility studies were included in this test, slopes were computed for each crater's side slopes. At least six separate surveyed slopes were analyzed for each crater; the results are listed in Table 4. These slopes are not the true slopes that would be encountered by a tracked or wheeled vehicle nor do they account for soil conditions and traction. They do, however, give an indication of the minimum slope a vehicle would have to climb to exit the craters. In most cases the actual slopes would be steeper because of the slumping of material near the bottom of the crater.

\section{TIME AND LABOR STUDIES}

32. Specific comparisons of the various designs with regard to the time and labor required to implement them were extremely difficult to make since each unit used different methods to accomplish, to train for, and to administratively and logistically prepare for the mission. The use of platoon-sized units generally meant that excess labor was available.

33. Some general observations can be summarized:

a. There appears to be no time or labor savings in using slurry rather than cratering canisters. While the slurry can be loaded in irregular and smaller diameter holes, the tools available for digging or cleaning out the holes will make an emplacement hole wide enough to easily accept the canister charge.

$b$. The use of slurry resulted in a more compact charge because it slumped in the hole, completely filling it. It was of ten necessary to place stemming material along the sides of the standard cratering charges, a difficult procedure in the soils encountered at all three sites.

c. If smaller than platoon-sized units were assigned a road cratering mission, they would require less time and energy to implement the three-hole designs simply because there is less digging involved.

$d$. The most significant time and labor factor in road cratering is the preparation of emplacement holes. One demolition specialist has enough time to easily prepare all charges and accessories while the holes are being excavated to their required depths. 
Table 2

DRC Apparent Dimensions

\begin{tabular}{|c|c|c|c|c|c|c|c|c|c|}
\hline \multirow[b]{2}{*}{ Design } & \multirow[b]{2}{*}{ Site } & \multicolumn{2}{|c|}{$D_{a}{ }^{*}$} & \multicolumn{2}{|c|}{$\mathrm{W}_{\mathrm{a}}{ }^{* *}$} & \multicolumn{2}{|c|}{$\mathrm{L}_{\mathrm{a}}{ }^{* *}$} & \multicolumn{2}{|c|}{$\mathbf{v}_{\mathbf{a}} \dagger$} \\
\hline & & $\mathrm{ft}$ & $\bar{m}$ & ft & $\mathbf{m}$ & $\mathrm{ft}$ & $\mathbf{m}$ & $\overline{\mathrm{yd}^{3}}$ & $\underline{\mathbf{m}^{3}}$ \\
\hline Al & I & 7.1 & 2.16 & 24.7 & 7.53 & 44.0 & 13.41 & 116 & 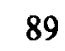 \\
\hline $\mathrm{A} 2$ & I & 6.7 & 2.04 & 22.5 & 6.86 & 40.8 & 12.44 & 81 & 62 \\
\hline A3 & III & 6.1 & 1.86 & 20.1 & 6.13 & 37.9 & 11.55 & 72 & 55 \\
\hline BI & I & 6.6 & 2.01 & 23.3 & 7.10 & 26.0 & 7.92 & 43 & 33 \\
\hline B2 & I & 6.9 & 2.10 & 25.4 & 7.74 & 45.7 & 13.93 & 97 & 1 \\
\hline B3 & III & 6.7 & 2.04 & 19.8 & 6.04 & 40.9 & 12.47 & 68 & 52 \\
\hline $\mathrm{Cl}$ & 1 & 7.8 & 2.38 & 24.2 & 7.38 & 41.1 & 12.53 & 115 & 88 \\
\hline $\mathrm{C} 2$ & I & 5.7 & 1.74 & 17.3 & 5.27 & 41.0 & 12.50 & 80 & 61 \\
\hline D1 & I & 9.7 & 2.96 & 30.5 & 9.30 & 45.1 & 13.75 & 186 & 142 \\
\hline D2 & I & 6.0 & 1.83 & 22.7 & 6.92 & 43.6 & 13.29 & 81 & 62 \\
\hline D3 & III & 9.7 & 2.96 & 28.0 & 8.53 & 52.0 & 15.85 & 267 & 204 \\
\hline D4 & II & 6.2 & 1.89 & 37.0 & 11.28 & 44.3 & 13.50 & 86 & 66 \\
\hline El & III & 5.0 & 1.52 & 13.6 & 4.15 & 38.8 & 11.83 & 42 & 32 \\
\hline E2 & I & 7.5 & 2.29 & 21.0 & 6.40 & 36.0 & 10.97 & 81 & 62 \\
\hline E3 & III & 6.8 & 2.07 & 24.4 & 7.44 & 56.0 & 17.07 & 101 & 77 \\
\hline Fl & III & 5.6 & $1.7 \mathrm{I}$ & 19.0 & 5.79 & 36.0 & 10.97 & 59 & 45 \\
\hline F2 & I & 7.3 & 2.23 & 19.0 & 5.79 & 37.9 & 11.55 & 74 & 57 \\
\hline F3 & II & 5.6 & 1.71 & 22.8 & 6.95 & 36.3 & 11.06 & 55 & 42 \\
\hline G1 & I & 8.6 & 2.62 & 27.5 & 8.38 & 45.2 & 13.78 & 151 & 115 \\
\hline G2 & I & 7.1 & 2.16 & 20.8 & 6.34 & 43.4 & 13.23 & 93 & \\
\hline G3 & II & 6.2 & 1.89 & 22.3 & 6.80 & 39.6 & 12.07 & 80 & 01 \\
\hline
\end{tabular}

Note: Two end charges did not fire on B1 test. Long crater due to blasting on elevated roadway for tests D3 and E3.

* Maximum depth of apparent crater below and normal to original ground surface.

** Width and length of apparent crater measured at original ground, respectively.

$\dagger$ Volume of apparent crater below original ground surface. 
Table 3

DRC Obstacle Dimensions

\begin{tabular}{|c|c|c|c|c|c|c|c|}
\hline \multirow[b]{2}{*}{ Design } & \multirow[b]{2}{*}{ Site } & \multicolumn{2}{|c|}{$\mathbf{D}_{\mathrm{ob}}{ }^{*}$} & \multicolumn{2}{|c|}{$\mathrm{W}_{\mathrm{ob}}{ }^{* *}$} & \multicolumn{2}{|c|}{$\mathbf{L}_{\mathbf{o b}}{ }^{* *}$} \\
\hline & & $\mathrm{ft}$ & $\underline{m}$ & $\mathrm{ft}$ & $\mathbf{m}$ & $\mathrm{ft}$ & $\mathbf{m}$ \\
\hline $\begin{array}{l}\text { A1 } \\
\text { A2 } \\
\text { A3 }\end{array}$ & $\begin{array}{l}\text { I } \\
\text { I } \\
\text { III }\end{array}$ & $\begin{array}{r}10.1 \\
9.8 \\
7.6\end{array}$ & $\begin{array}{l}3.1 \\
3.0 \\
2.3\end{array}$ & $\begin{array}{l}32.0 \\
28.0 \\
25.0\end{array}$ & $\begin{array}{l}9.8 \\
8.5 \\
7.6\end{array}$ & $\begin{array}{l}46.0 \\
43.0 \\
42.0\end{array}$ & $\begin{array}{l}14.0 \\
13.1 \\
12.8\end{array}$ \\
\hline $\begin{array}{l}\text { B1 } \\
\text { B2 } \\
\text { B3 }\end{array}$ & $\begin{array}{l}\text { I } \\
\text { I } \\
\text { III }\end{array}$ & $\begin{array}{l}8.3 \\
9.5 \\
8.3\end{array}$ & $\begin{array}{l}2.5 \\
2.9 \\
2.5\end{array}$ & $\begin{array}{l}26.0 \\
30.5 \\
25.0\end{array}$ & $\begin{array}{l}7.9 \\
9.3 \\
7.6\end{array}$ & $\begin{array}{l}26.0 \\
47.5 \\
45.0\end{array}$ & $\begin{array}{r}7.9 \\
14.5 \\
13.7\end{array}$ \\
\hline $\begin{array}{l}\mathrm{C} 1 \\
\mathrm{C} 2\end{array}$ & I & $\begin{array}{r}12.0 \\
8.0\end{array}$ & $\begin{array}{l}3.7 \\
2.4\end{array}$ & $\begin{array}{l}30.0 \\
23.0\end{array}$ & $\begin{array}{l}9.1 \\
7.0\end{array}$ & $\begin{array}{l}43.0 \\
41.0\end{array}$ & $\begin{array}{l}13.1 \\
12.5\end{array}$ \\
\hline $\begin{array}{l}\text { D1 } \\
\text { D2 } \\
\text { D3 } \\
\text { D4 }\end{array}$ & $\begin{array}{l}\text { I } \\
\text { I } \\
\text { III } \\
\text { II }\end{array}$ & $\begin{array}{r}15.1 \\
10.4 \\
13.7 \\
8.0\end{array}$ & $\begin{array}{l}4.6 \\
3.2 \\
4.2 \\
2.4\end{array}$ & $\begin{array}{l}38.0 \\
26.0 \\
44.0 \\
38.0\end{array}$ & $\begin{array}{r}11.6 \\
7.9 \\
13.4 \\
11.6\end{array}$ & $\begin{array}{l}48.0 \\
44.0 \\
60.0 \\
48.0\end{array}$ & $\begin{array}{l}14.6 \\
13.4 \\
18.3 \\
14.6\end{array}$ \\
\hline $\begin{array}{l}\text { E1 } \\
\text { E2 } \\
\text { E3 }\end{array}$ & $\begin{array}{l}\text { III } \\
\text { I } \\
\text { III }\end{array}$ & $\begin{array}{l}5.1 \\
7.9 \\
7.9\end{array}$ & $\begin{array}{l}1.6 \\
2.4 \\
2.4\end{array}$ & $\begin{array}{l}18.0 \\
24.0 \\
29.0\end{array}$ & $\begin{array}{l}5.5 \\
7.3 \\
8.8\end{array}$ & $\begin{array}{l}39.0 \\
36.0 \\
56.0^{* *}\end{array}$ & $\begin{array}{l}11.9 \\
11.0 \\
17.1\end{array}$ \\
\hline $\begin{array}{l}\text { F1 } \\
\text { F2 } \\
\text { F3 }\end{array}$ & $\begin{array}{l}\text { III } \\
\text { I } \\
\text { II }\end{array}$ & $\begin{array}{l}6.3 \\
9.3 \\
6.7\end{array}$ & $\begin{array}{l}1.9 \\
2.8 \\
2.0\end{array}$ & $\begin{array}{l}24.0 \\
26.5 \\
34.0\end{array}$ & $\begin{array}{r}7.3 \\
8.1 \\
10.4\end{array}$ & $\begin{array}{l}38.0 \\
40.0 \\
38.0\end{array}$ & $\begin{array}{l}11.6 \\
12.2 \\
11.6\end{array}$ \\
\hline $\begin{array}{l}\text { G1 } \\
\text { G2 } \\
\text { G3 }\end{array}$ & $\begin{array}{l}\text { I } \\
\text { I } \\
\text { II }\end{array}$ & $\begin{array}{r}11.8 \\
9.7 \\
7.3\end{array}$ & $\begin{array}{l}3.6 \\
3.0 \\
2.2\end{array}$ & $\begin{array}{l}34.0 \\
30.0 \\
33.0\end{array}$ & $\begin{array}{r}10.4 \\
9.1 \\
10.1\end{array}$ & $\begin{array}{l}48.0 \\
46.5 \\
44.0\end{array}$ & $\begin{array}{l}14.6 \\
14.2 \\
13.4\end{array}$ \\
\hline
\end{tabular}

Note: Two end charges did not fire on B1 test. Long crater due to blasting on elevated roadway for tests D3 and E3.

* Maximum depth of the crater as an obstacle from the lip crest to the bottom.

** Width and length of crater as an obstacle measured from lip crest to lip crest. 
Table 4

Side Slopes of Raystown Craters

\begin{tabular}{lccc}
\hline Design & Average Slope & Steepest & Least Steep \\
\cline { 2 - 3 } A1 & 0.619 & 0.664 & 0.563 \\
A2 & 0.594 & 0.670 & 0.490 \\
A3 & 0.592 & 0.678 & 0.519 \\
B1* & 0.468 & 0.600 & 0.262 \\
B2 & 0.537 & 0.638 & 0.338 \\
B3 & 0.594 & 0.733 & 0.528 \\
C1 & 0.647 & 0.724 & 0.525 \\
C2 & 0.589 & 0.728 & 0.440 \\
D1 & 0.713 & 0.552 \\
D2 & 0.645 & 0.616 & 0.474 \\
D3 & 0.541 & 0.579 & 0.516 \\
D4 & 0.547 & 0.611 & 0.411 \\
E1 & 0.549 & 0.750 & 0.457 \\
E2 & 0.620 & 0.717 & 0.614 \\
E3 & 0.665 & 0.623 & 0.452 \\
F1 & 0.529 & 0.645 & 0.485 \\
F2 & 0.541 & 0.691 & 0.506 \\
F3 & 0.594 & 0.688 & 0.310 \\
G1 & 0.536 & 0.663 & 0.608 \\
G2 & 0.642 & 0.664 & 0.434 \\
G3 & 0.574 & 0.628 & 0.418 \\
& 0.498 & &
\end{tabular}

* Did not detonate completely. 


\section{PART IV: ANALYSIS}

\section{EXPLOSIVE COMPARISON}

34. It is possible to compare directly the performance of the military cratering charge and the slurry on six of the designs used during this test. Designs $A$ and $B$ used the same charge size and configuration ( 5 holes, $320 \mathrm{lb}(145 \mathrm{~kg}$ ) of explosive). Design A was executed using the standard cratering charge, whereas design $B$ used the slurry. Designs $C$ and $D$ were the same except for the explosive type; design D used the slurry. Lastly, designs $\mathrm{E}$ and $\mathrm{F}$ were the same except that the slurry was used in design $\mathrm{F}$.

35. Comparisons of performance have been made between the similar designs of the three groups. The results of the detonations using the standard military cratering charges were used as the standards for these comparisons; the parameter used for the comparisons is crater volume. Because the designs using slurry were fired at different locations, it was necessary to choose the military cratering-charge shots fired at the same locations as references. In most cases comparable shots (canister and slurry) were fired adjacent to each other so that the influence of differences in soil conditions was minimized. Results of this comparison are presented in Table 5.

36. This direct comparison shows that, except for the misfire (design $\mathrm{B} 1$ ), the slurry performed at least as well as the $40-\mathrm{lb}(18.1-\mathrm{kg})$ cratering charge in the standard deliberate road crater, i.e. designs A and $\mathrm{B}$. The slurry performed slightly better than the military cratering charges in the two three-hole (modified DRC) designs; i.e. designs $\mathrm{C}$ and $\mathrm{D}$ and designs $\mathrm{E}$ and $\mathrm{F}$. The slurry's higher energy and its capacity for coupling more directly with the media are the most likely reasons for the superior performance.

37. There was no discernible difference in the time or labor required to emplace comparable explosive charges. As mentioned previously, the equipment used to clean and deepen the initial emplacement hole created by the shaped charges provided enough room to load the canisters easily. The walls of the tapered holes preduced by the shaped charges were rough and irregular, but it was evident that the slurry could have been used directly in such an emplacement hole because it readily slumped, completely filling the hole. More care must be used in loading the slurry because it tends to dislodge loose material from the sides of the hole when dropped (Figure 11). A minor problem with the slurry was that it had a slightly sticky consistency. It also tended to flip over and bridge the slant holes during loading. It was necessary to use a shovel handle to push through the charge, thereby allowing trapped air to escape and the slurry to sink to the bottom of the hole. This problem did not exist on the vertical emplacement holes.

38. Both explosives were simple and easy to store. There was no evidence of gel breakdown for the slurry manufactured on 28 April 1973. The slurry was used in several water-filled holes with excellent results. Of particular note was design B3 which was fired in water-filled holes that were wide and shallow. Despite the shallow depth of the charges, the resulting crater was practically the same size as the adjacent one (design A3) fired with military cratering charges in deeper, dry holes.

39. The possibility that some of the slurry explosive burned in the air (see Part III) could be due to insufficient oxygen in the slurry mixture to completely oxidize the aluminum. The aluminum-oxygen reaction would therefore not be completed until additional oxygen is available from the air when the material from the crater is ejected. This condition could account for the white residue found in the crater and its ejecta field. 


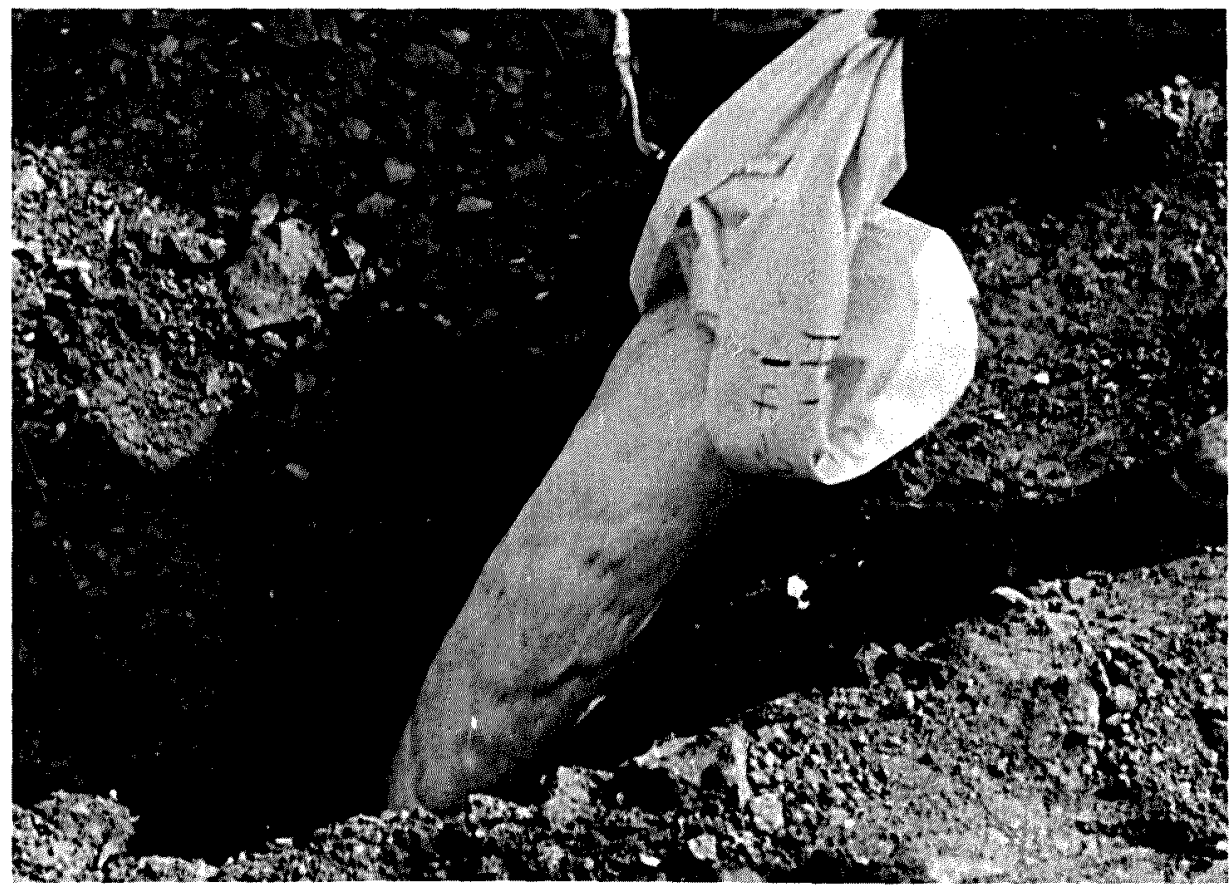

Figure 11. Slurry being poured downhole

\section{DESIGN COMPARISON}

40. Design $\mathrm{A}$, the current DRC design used by the Army, requires three $80-\mathrm{lb}(36.3-\mathrm{kg})$ charges spaced $10 \mathrm{ft}(3.05 \mathrm{~m})$ apart and buried in $7-\mathrm{ft}(2.13-\mathrm{m})$ holes, and two $40-\mathrm{lb}(18.1-\mathrm{kg})$ charges in $5-\mathrm{ft}(1.52-$ $\mathrm{m}$ ) holes spaced between them. The three-hole designs were intended to take advantage of the greater energy and coupling ability of the slurry, and it was also believed that they would require less time to execute. Designs $\mathrm{C}, \mathrm{D}$, and $\mathrm{G}$ retained the $10-\mathrm{ft}(3.05-\mathrm{m})$ spacing between charges, but eliminated the intermediate holes. The charge weight in each hole was $120 \mathrm{lb}(54.4 \mathrm{~kg})$. Designs $\mathrm{E}$ and $\mathrm{F}$ decreased the spacing between holes to $8 \mathrm{ft}(2.44 \mathrm{~m})$, but the charge weight was maintained at the standard $80 \mathrm{lb}$ $(36.3 \mathrm{~kg})$.

41. It is possible to directly compare the DRC design executed using the $40-\mathrm{lb}(18.1-\mathrm{kg})$ cratering charge with the two different three-hole designs used. In Table 6, the three-hole designs are compared with the crater volume of the DRC design (design A) which is used as the reference. The three different design $\mathrm{A}$ volumes used correspond to the three different sites.

42. The comparison shows that the three-hole designs performed at least as well as the standard deliberate road crater. This was expected due to the increased energy in both the new formulation used in the $40-\mathrm{lb}(18.1-\mathrm{kg})$ cratering charge and the aluminized slurry. The use of larger slurry charges in designs $\mathrm{D}$ and $\mathrm{G}$ resulted in craters that were consistently larger than those produced by the standard design.

\section{TIME AND MANPOWER COMPARISONS}

43. Time studies yielded very little quantitative information. Logistics problems and the various 
methods by which the mission was handled by the different platoons made meaningful times hard to obtain. It was readily apparent that excavation of the emplacement holes took the largest share of time and manpower. Site III, the hardtop road with limestone base course, proved the most difficult to excavate because of base-course rocks falling into the hole created by a shaped charge. Excavating these holes with the posthole digger was slow and tedious. Both the three-and five-hole designs took about the same time because of the requirement to excavate three holes to $7 \mathrm{ft}$ in each design. If the emplacement holes were drilled with motorized equipment, the three-hole designs would require less time to dig the holes and to prepare and place the charges. There appeared to be no appreciable difference between effort expended preparing and setting the cratering canisters and the military slurry.

44. The overriding requirement for manpower was digging the emplacement holes. One demolition specialist could easily have all charges prepared before the holes were ready. Less manpower is required for the three-hole design because there are two fewer shaped charges and two fewer holes to dig. Because the holes are not as close together as in the five-hole design, it was also easier to work at all three simultaneously without disturbing the adjacent holes.

\section{MEDIA EFFECTS}

45. Comparing the craters at Raystown with those produced during Project AOII demonstrates the effects various media can have on cratering performance. The AOII charge arrays excavated craters with total volumes from 20 to $47 \mathrm{yd}^{3}$ ( 15 to $36 \mathrm{~m}^{3}$ ) in Bearpaw clay shale.* The smallest craters at Raystown were at least as big as the largest at AOII, and most were two or three times larger. The relatively more energetic explosives used at Raystown account for some of these differences, but it is believed that the greatest factor is the higher compaction and moisture content of the Raystown soils compared with the Bearpaw shale.

46. It has been previously observed that high moisture content of a soil usually increases cratering effectiveness. This effect was demonstrated at site I where craters Al, D1, and G1 were fired at the low end of the road near the reservoir level. The remaining craters were fired at higher elevations in the road and were at least 30 percent smaller. The same effect was partially evident at site IIl. Designs El and F1 were fired during the first week of operations when the road and surrounding country were quite dry, and these were two of the smallest craters. Four more shots were fired at this site during the third week, by which time the reservoir had backed up into the valley around this road. Despite difficulty in digging emplacement holes to $5 \mathrm{ft}$, the craters were much larger. Figures 12-14 show typical craters at the three different sites.

\section{MISCELLANEOUS}

47. Overall, the military demolition equipment and explosives used on this project performed well. An inherent problem when using shaped charges close together with field expedient standoffs (Appendix A) is that occasionally one will be knocked down or off line prior to detonating. The only other problems occurred when WD-1/TT communications wire was used as a firing line. Conditions were usually wet or muddy, close to $1000 \mathrm{ft}(300 \mathrm{~m})$ of wire was used, and this wire usually had several splices in it. Several times caps failed to detonate even though the continuity check indicated a good

* Briggs, op. cit. 


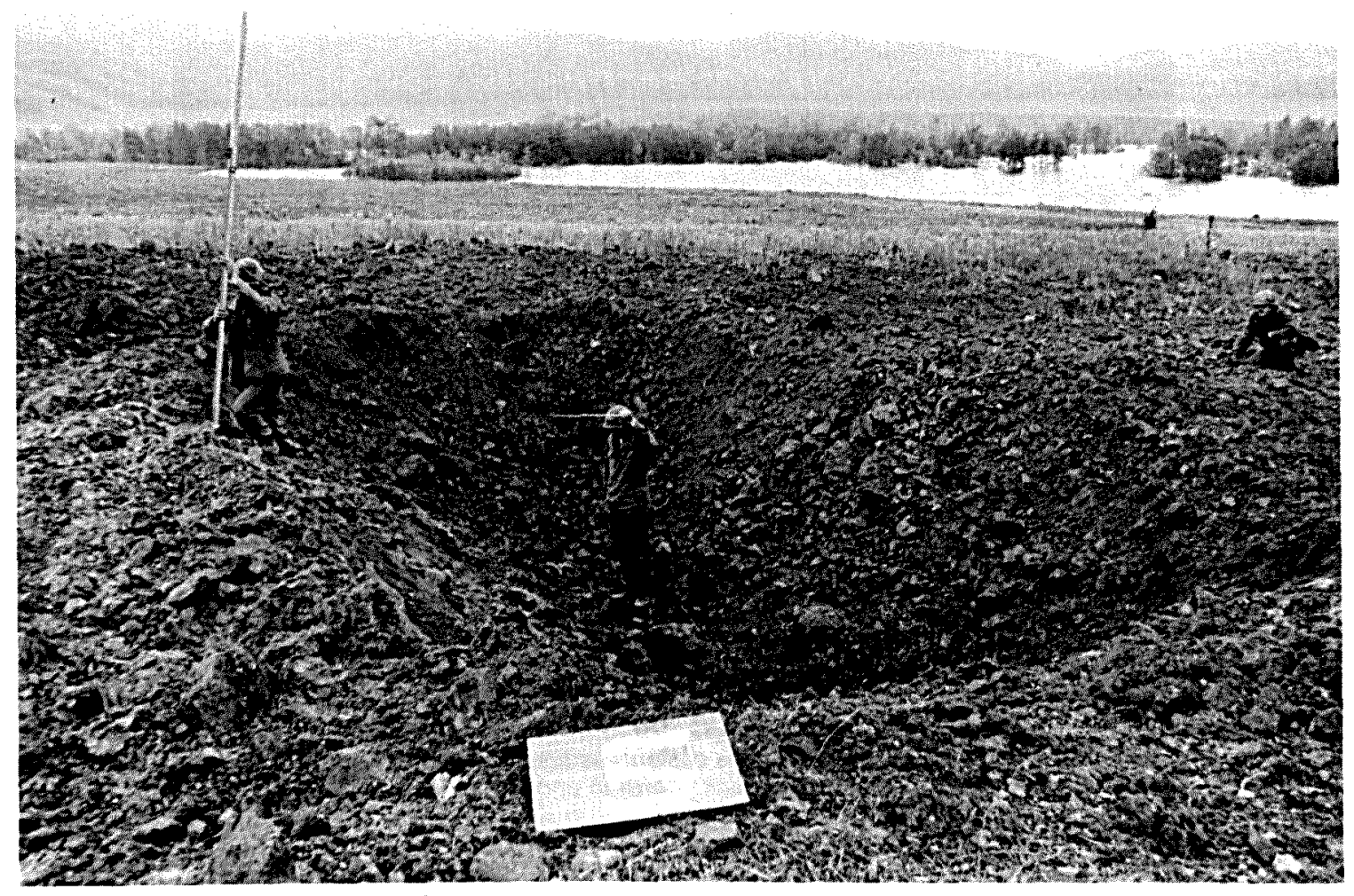

Figure 12. Design E1 fired at site I

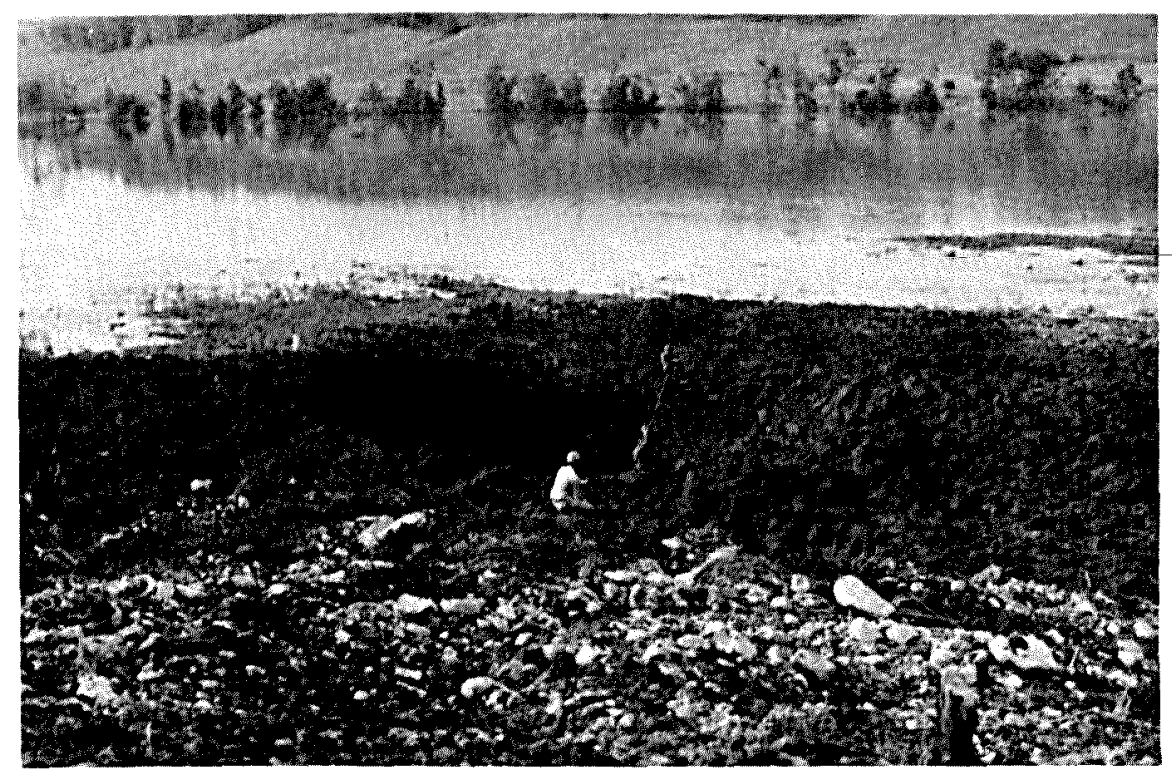

Figure 13. Design E3 fired at site III after water had entered valley 


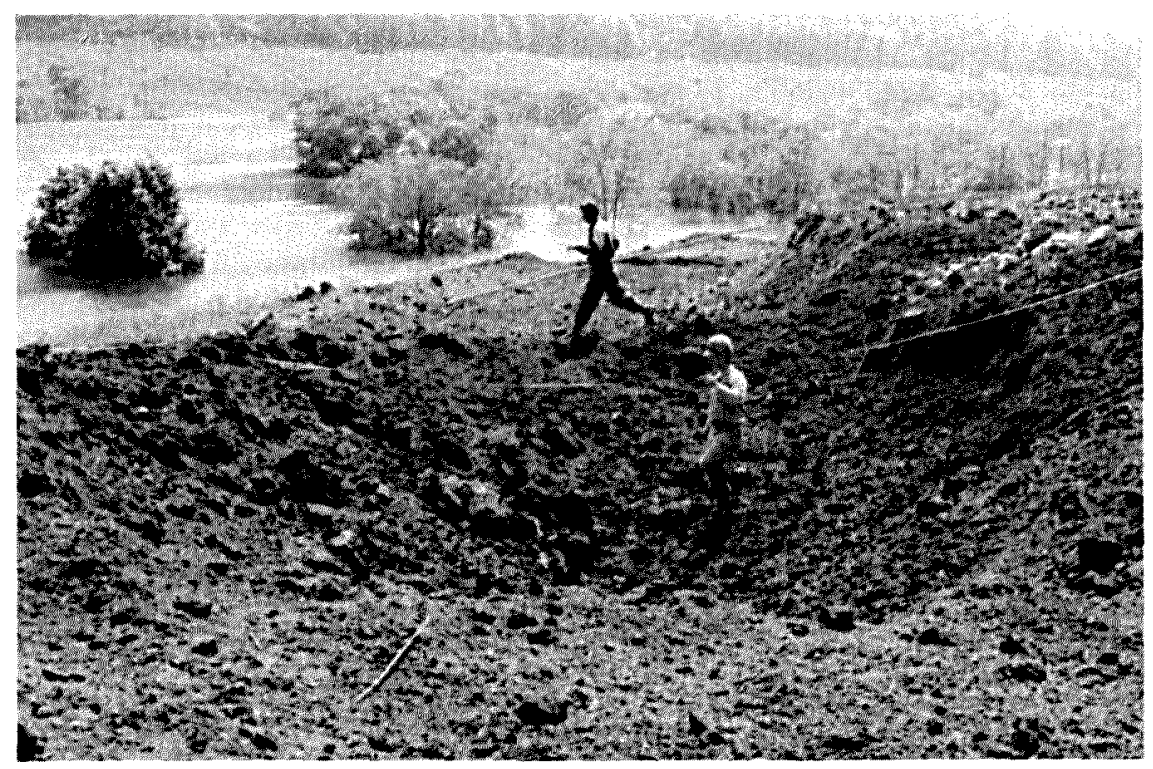

Figure 14. Design F3 fired at site 11. This design was fired parallel to the road due to high uphill bank shown in photo

firing line. This required walking along the wire, checking and retaping splices, and watching for areas where the wire had kinked or had been smashed and the insulation broken; this was a long and tedious operation.

48. As emplacement holes progressed deeper than $5 \mathrm{ft}$ and the auger had to be used, digging was usually made easier by adding water to the hole. This wetting made the material more cohesive and kept it from sliding out the sides of the auger. Using the auger to dig in dry, cohesionless material was a slow, tedious process. 
Table 5

Volumes Excavated by Aluminized Slurry and Military Cratering Charge

\begin{tabular}{|c|c|c|c|c|c|c|}
\hline \multirow{2}{*}{$\begin{array}{l}\text { Slurry } \\
\text { Design } \\
\end{array}$} & \multicolumn{2}{|c|}{$\begin{array}{l}\text { Volume Produced } \\
\text { by Slurry Design }\end{array}$} & \multirow{2}{*}{$\begin{array}{c}\text { Reference Cratering } \\
\text { Charge Design* } \\
\end{array}$} & \multicolumn{2}{|c|}{$\begin{array}{c}\text { Volume Produced by } \\
\text { Standard Cratering } \\
\text { Charge Design } \\
\end{array}$} & \multirow{2}{*}{$\%\left(\frac{\text { Slurry Volume }}{\text { Reference Volume }}\right)$} \\
\hline & $\mathrm{yd}^{3}$ & $\mathbf{m}^{3}$ & & $\mathrm{yd}^{3}$ & $\mathrm{~m}^{3}$ & \\
\hline $\begin{array}{l}\mathrm{B} 1^{* *} \\
\mathrm{~B} 2 \\
\mathrm{B3}\end{array}$ & $\begin{array}{l}43 \\
97 \\
68\end{array}$ & $\begin{array}{l}33 \\
73 \\
50\end{array}$ & $\begin{array}{l}\text { A1 } \\
\text { A2 } \\
\text { A3 }\end{array}$ & $\begin{array}{r}116 \\
81 \\
72\end{array}$ & $\begin{array}{l}89 \\
62 \\
55\end{array}$ & $\begin{array}{r}37.0 \\
119.8 \\
94.4\end{array}$ \\
\hline $\begin{array}{l}\text { D1 } \\
\text { D2 }\end{array}$ & $\begin{array}{r}186 \\
81\end{array}$ & $\begin{array}{r}142 \\
62\end{array}$ & $\begin{array}{l}\mathrm{Cl} \\
\mathrm{C} 2\end{array}$ & $\begin{array}{r}115 \\
80\end{array}$ & $\begin{array}{l}88 \\
61\end{array}$ & $\begin{array}{l}161.7 \\
101.3\end{array}$ \\
\hline $\begin{array}{l}\mathrm{F} 1 \\
\mathrm{~F} 2\end{array}$ & $\begin{array}{l}59 \\
74\end{array}$ & $\begin{array}{l}45 \\
57\end{array}$ & $\begin{array}{l}\text { E1 } \\
\text { E2 }\end{array}$ & $\begin{array}{l}42 \\
81\end{array}$ & $\begin{array}{l}32 \\
62\end{array}$ & $\begin{array}{r}140.5 \\
91.4\end{array}$ \\
\hline
\end{tabular}

* This design is identical with the corresponding slurry design in site location as well as charge size and configuration. It was executed using military cratering charges.

** This shot did not completely detonate.

Table 6

Comparison of the Three-Hole DRC Designs and the Army's Five-Hole Deliberate Road Crater Design

\begin{tabular}{|c|c|c|c|c|c|}
\hline \multirow[b]{2}{*}{ Design* } & \multicolumn{2}{|c|}{$\begin{array}{c}\text { Reference } \\
\text { Volume*,** }\end{array}$} & \multicolumn{2}{|c|}{ Test Volume } & \multirow[b]{2}{*}{ Percent Difference } \\
\hline & $\overline{y^{3}}$ & $\underline{\mathbf{m}^{3}}$ & $\underline{\mathbf{y d}^{3}}$ & $\mathbf{m}^{3}$ & \\
\hline \multicolumn{6}{|c|}{ Three-Hole Design, Holes $10 \mathrm{ft}(3.05 \mathrm{~m})$ Apart, $120 \mathrm{lb}(54.4 \mathrm{~kg}) /$ Hole } \\
\hline $\begin{array}{l}\mathrm{C} 1 \\
\mathrm{C} 2\end{array}$ & $\begin{array}{r}116 \\
81\end{array}$ & $\begin{array}{l}89 \\
62\end{array}$ & $\begin{array}{r}115 \\
80\end{array}$ & $\begin{array}{l}88 \\
61\end{array}$ & $\begin{array}{l}-1 \\
-1\end{array}$ \\
\hline $\begin{array}{l}\text { D1 } \\
\text { D2 } \\
\text { D3 }\end{array}$ & $\begin{array}{r}116 \\
81 \\
72\end{array}$ & $\begin{array}{l}89 \\
62 \\
55\end{array}$ & $\begin{array}{r}186 \\
81 \\
267\end{array}$ & $\begin{array}{r}142 \\
62 \\
204\end{array}$ & $\begin{array}{r}+60 \\
0 \\
+271\end{array}$ \\
\hline $\begin{array}{l}\text { G1 } \\
\text { G2 }\end{array}$ & $\begin{array}{r}116 \\
81\end{array}$ & $\begin{array}{l}89 \\
62\end{array}$ & $\begin{array}{r}151 \\
93\end{array}$ & $\begin{array}{r}115 \\
71\end{array}$ & $\begin{array}{l}+30 \\
+15\end{array}$ \\
\hline \multicolumn{6}{|c|}{ Three-Hole Design, Holes $8 \mathrm{ft}(2.44 \mathrm{~m})$ Apart, $80 \mathrm{lb}(36.3 \mathrm{~kg}) /$ Hole } \\
\hline $\begin{array}{l}\text { E1 } \\
\text { E2 } \\
\text { E3 }\end{array}$ & $\begin{array}{l}72 \\
81 \\
72\end{array}$ & $\begin{array}{l}55 \\
62 \\
55\end{array}$ & $\begin{array}{r}42 \\
81 \\
101\end{array}$ & $\begin{array}{l}32 \\
62 \\
77\end{array}$ & $\begin{array}{r}-42 \\
0 \\
+40\end{array}$ \\
\hline $\begin{array}{l}\mathrm{F} 1 \\
\mathrm{~F} 2\end{array}$ & $\begin{array}{l}72 \\
81\end{array}$ & $\begin{array}{l}55 \\
62\end{array}$ & $\begin{array}{l}59 \\
74\end{array}$ & $\begin{array}{l}45 \\
57\end{array}$ & $\begin{array}{r}-18 \\
-9\end{array}$ \\
\hline
\end{tabular}

* Design A, the Army's DRC, used as reference volume.

** Base volumes differ due to different locations where shots were fired. 


\section{PART V: CONCLUSIONS}

49. The results of the Project RAYSTOWN work are encouraging and instructive with respect to both the explosives and designs used, and the field evaluations of actual troop operations.

50. In general, the slurry performed at least as well as the military cratering charge. It performed better than the canisters in the three-hole designs. It was easy to handle and filled the irregular-shaped cavities quite well. If the shaped charges had been able to produce clean holes to the desired depths, the slurry could possibly have been loaded immediately, whereas remedial digging would still have been required to obtain a cavity wide enough to accommodate the cratering canister. The slurry performed well underwater.

51. The three-hole designs resulted in craters that compared favorably with the standard DRC design. The slurry performed well in all designs, with designs $\mathrm{D}$ and $\mathrm{G}$ (3- to 7-ft (0.9- to 2.1-m) holes and $120-\mathrm{lb}(54.4-\mathrm{kg}) /$ hole) being the most effective. There was little or no difference between the results of the slant hole design (G) and the results of the straight hole design (D). The slant holes were easier to excavate, but more difficult to load due to occasional bridging of the hole by the slurry.

52. The most important aspect of the cratering operations was the time and manpower required to dig the emplacement holes to the required depths. The presence of rocks and cobbles and material falling back into the hole made digging slow, tedious, and sometimes impossible. It was necessary to relieve crews frequently to insure a sustained effort. This operation appeared to be the most critical and it required the most time and manpower. Research and development efforts should be continued to find faster and easier methods to make emplacement holes. Any effect of differences in soil types on cratering was not discernible at the three sites. Cratering performance was improved for the shots detonated near the reservoir level where moisture in the soil exceeded the moisture content of the soils at higher road elevations.

53. With the exception of WD-1 communications wire, the equipment in the demolition kit proved reliable and easy to handle. A better type of splice connector, a more sophisticated circuit tester, or a more powerful blasting machine should be studied if this wire is to be used to any extent throughout the Army.

54. Project RAYSTOWN demonstrated the suitability of a slurry for a road cratering mission and the advantages of different cratering designs that use the slurry's energy more efficiently. The field program again highlighted the necessity of a better method of making emplacement holes if road cratering is to become a fast, efficient operation. 


\section{APPENDIX A: EMPLACEMENT HOLE OPERATIONS}

\section{INTRODUCTION}

1. Shaped charges were used to create the emplacement holes. A detailed study of this part of the operation was not originally planned, but the field results were tabulated and offer excellent records of what can be expected of $40-\mathrm{lb}(18.1-\mathrm{kg})$ shaped charges in soils similar to those found at Raystown.

\section{EXPLOSIVES}

\section{General}

2. The term "shaped charge" refers to explosives formed with a lined or unlined cavity in the end opposite to the ignition point. Lined-cavity shaped charges are the most effective. The detonating explosive progressively collapses the liner, focusing it into a high-velocity jet of particles. This jet has tremendous penetrating ability. Moving the charge away from the material (standoff) increases the penetrating depth up to some optimum standoff value; further increases in standoff then decrease the penetration.*

\section{Military Shaped Charge}

3. The 40-1b (18.1-kg) M3 demolition shaped charge (Lot No. JA1-5, loaded in May 1963) was the only shaped charge used on this project. The booster consists of approximately $50 \mathrm{~g}$ of Composition $\mathrm{A} 3$ (91 percent RDX and 6 percent wax). The main charge contains over $27 \mathrm{lb}(12 \mathrm{~kg}$ ) of Composition $B$. The charge comes with a metal pedestal which gives a $15-\mathrm{in} .(0.38-\mathrm{m})$ standoff or which can be used to hold the charge if greater standoffs are used.**

\section{OPERATIONS}

\section{Standoffs}

4. Several different standoffs were tried including 15,48 , and 60 in. $(0.38,1.22$, and $1.52 \mathrm{~m})$. The $15-$ in. $(0.38-\mathrm{m})$ standoff was obtained using the metal stand packed with the charge. Initially the 48 - and 60 in. (1.22- and 1.52-m) standoffs were obtained using saplings and taping them to the legs of the metal stand (Figure A1). This proved to be a workable arrangement, but was somewhat slow, unwieldy, and occasionally unstable. The final method consisted of driving a 5- or 6-ft $(1.5-$ or $1.8-\mathrm{m})$ picket into the ground and taping the stand to it (Figure A2). This provided a secure base and allowed better alignment of the charges with the varying ground slopes. There appear to be many expedient ways to obtain the desired standoff distances, even where slant holes are required.

5. The 48-in. (1.22-m) stand off was selected as the best for this type of material. The 15 -in. $(0.38-\mathrm{m})$ stand off tended to disrupt the surface which hindered the digging out of the hole and also produced shallower holes. Although little difference was noted between the 48- and 60-in. (1.22- and 1.52-m) stand offs, the 48 -in. (1.22-m) was easier to work with and control. Two wooden platforms and one metal

* Office, Chief of Engineers, Department of the Army, “Military Explosives," Technical Manual TM 9-1300-214, Nov 1967, Washington, D. C.

** Office, Chief of Engineers, op. cit. 


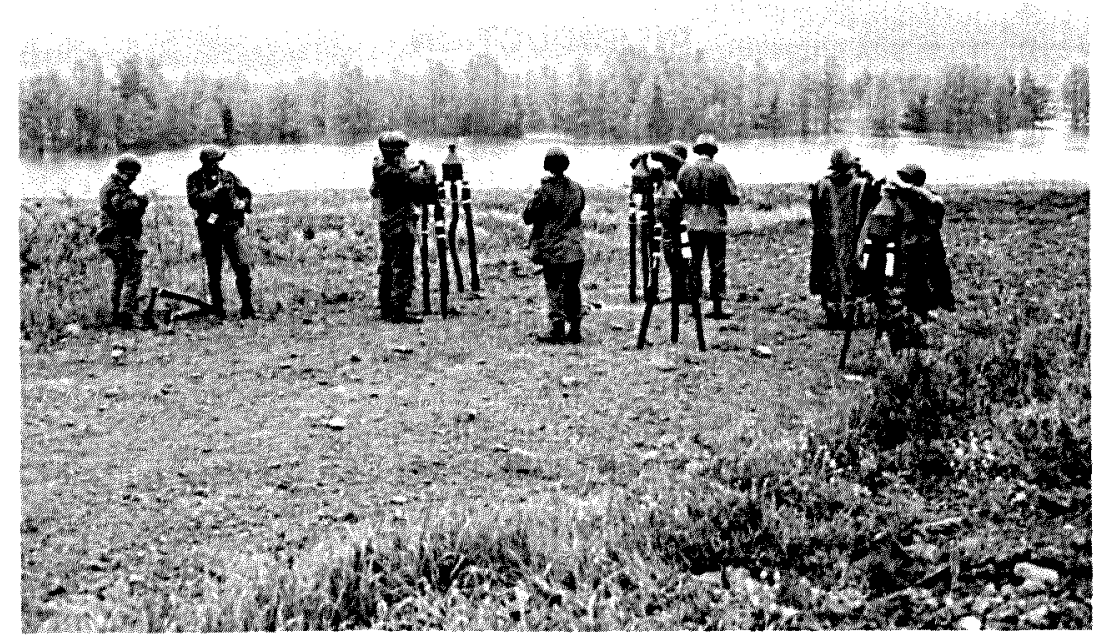

Figure A1. Shaped charges with wooden tripods used to obtain or achieve 48-in. standoffs

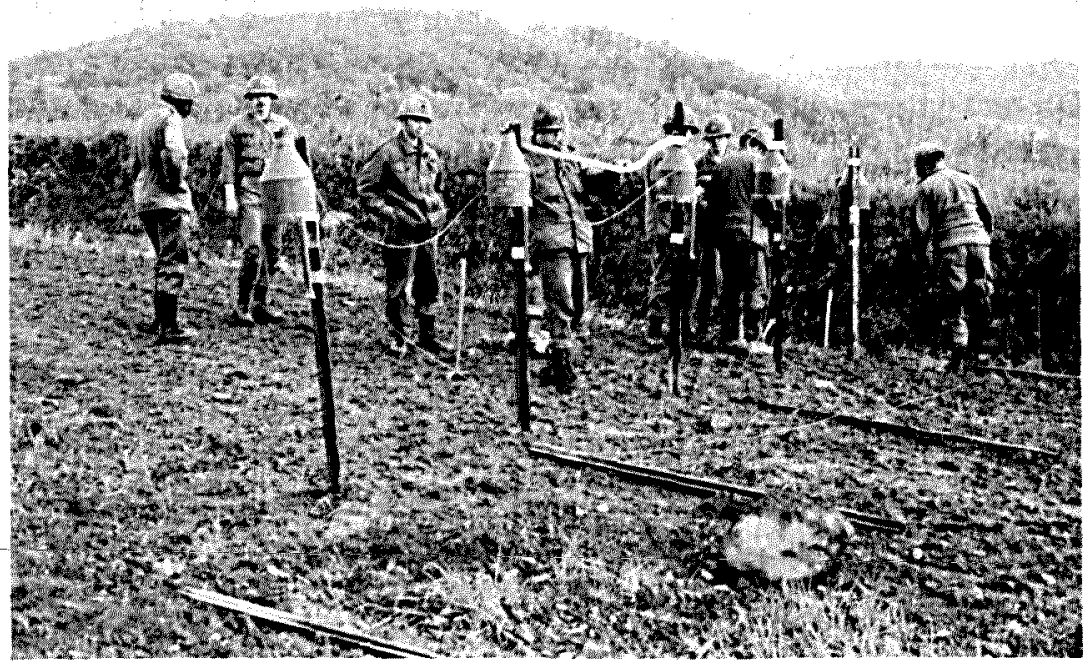

Figure A2. Shaped charges with metal pickets used to obtain 48-in. standoffs

picket failed during detonation and the charges fired but left no hole. This suggested that the adjoining blasts moved the supports prior to detonation. One charge failed to detonate for unexplained reasons. Examination of the charge revealed that it had been hit by fragments of adjoining charges and part of the casing was ripped off. The holes were subsequently filled with $\mathrm{C}-4$ and the charge fired successfully.

\section{Firing}

6. The arrays of shaped charges were fired electrically. An electric cap was attached to a ring-main of detonating cord. Detonating cord clips or a girth hitch with extra turn were used to make connections. 
Branch lines to each shaped charge were connected to a cap crimped to the end of the cord and secured inside the charge's cap well. Nonelectric blasting caps and primers from the M37 Demolition Charge Assembly were used. Firing lines were either 18-gage wire or WD1/TT communication wire. A blasting galvanometer was used to check the circuit and a 10-cap blasting machine was used throughout the exercise.

7. Holes were cleaned out using the tools found in the platoon's pioneer sets. Loose material was shovelled away from the top of the hole to avoid cave-ins and standard posthole diggers were then used. These were restricted to a depth of about $5 \mathrm{ft}(1.5 \mathrm{~m})$ due to their short handles and the limited space at lower depths to open the handles. The hand auger was then used to excavate to $7 \mathrm{ft}(2.1 \mathrm{~m})$ where required. Usually this was a two-man job as it was difficult for one man to lift an auger full of material out of the hole without losing it if the auger bucket hit the hole's side. Often the auger could not penetrate because of sandstone or shale rocks at the bottom or protruding from the hole's side. Attempts were made to remove the rocks with the posthole diggers and, if this was unsuccessful, the holes were loaded at whatever depth had been achieved. Figures A3 and A4 show holes being excavated with posthole diggers and augers. Both figures show the depression around the top $1 \mathrm{ft}(0.3 \mathrm{~m})$ of the hole caused by the shaped charge.

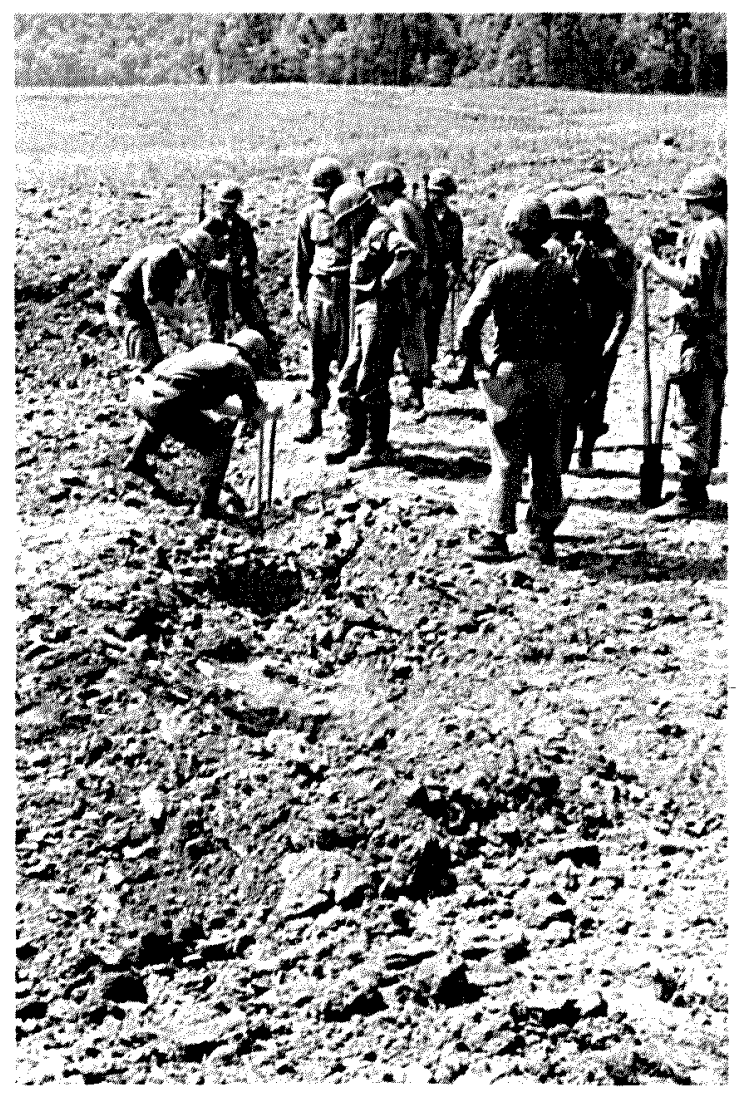

Figure A3. Posthole diggers being used to excavate emplacement holes

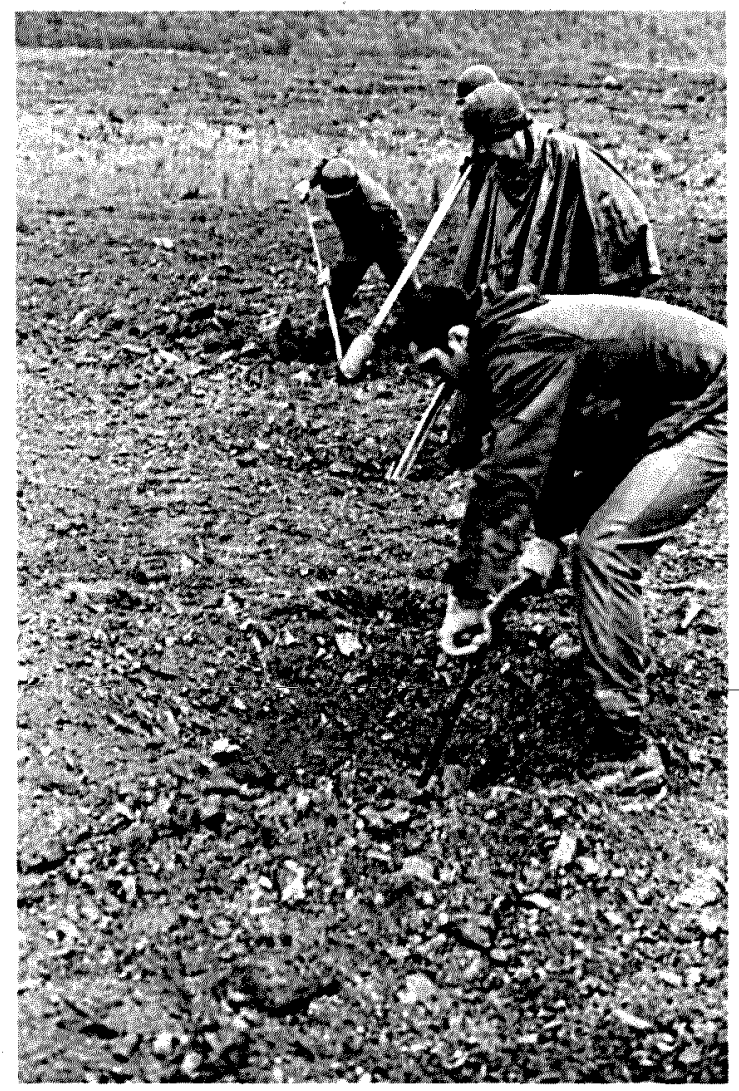

Figure A4. Posthole digger and hand auger being used to excavate slant holes of design $G$ 


\section{RESULTS}

8. The detonation of the shaped charges usually resulted in some surface disruption and the filling of the holes with loose material; this was especially true of the middle holes of an array. Sometimes the loose material only bridged the hole and the remainder of the hole was open once it was removed. It appeared that penetration was always $6 \mathrm{ft}(1.8 \mathrm{~m})$ or greater, but it was often difficult to dig to the required depth. Only the auger could be used below $5 \mathrm{ft}(1.5 \mathrm{~m})$ and it could not excavate rocks greater than $3 \mathrm{in.}(75 \mathrm{~mm})$ on a side. Large rocks in the side of a hole also stopped the auger's progress. The most difficult digging was at site III where the 3 -in. $(75-\mathrm{mm})$ base course of limestone was encountered, and where practically every hole was filled with base course which had fallen back (Figure A5). These holes were very difficult to fully excavate beyond $5 \mathrm{ft}(1.5 \mathrm{~m})$. In the dryer soils encountered (site $\mathrm{Il}$ ) below $5 \mathrm{ft}$ $(1.5 \mathrm{~m})$, adding a little water improved the material's cohesiveness and the auger's digging ability. While no slant holes were used at site III, at sites I and II these holes proved the easiest and fastest to clean out and dig.

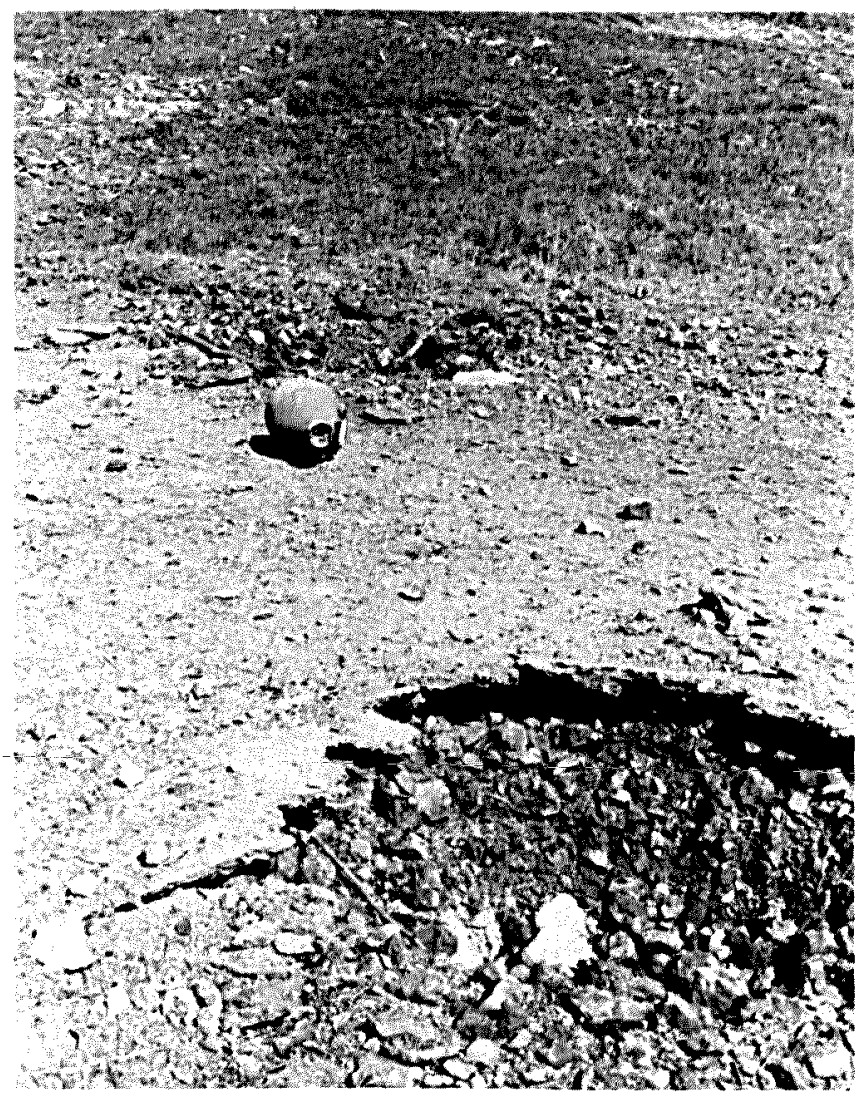

Figure A5. Shaped charge which failed to detonate and two shapedcharge holes filled with base-course material at site III

9. Table Al shows the results of emplacement-hole operations for the three different sites and the two hole depths required. This information clearly shows the difficulty encountered at site III and indicates that the easiest digging occurred at site 11 where very few large rocks were encountered. The 
average initial depth, the depth to which the hole was open prior to clean-out, varied from as deep as $7 \mathrm{ft}$ $(2.1 \mathrm{~m})$ to as shallow as $1 \mathrm{ft}(0.3 \mathrm{~m})$. Holes not finally excavated to the required depth were generally deeper than $6 \mathrm{ft}(1.8 \mathrm{~m})$, except at site III where holes as shallow as $2 \mathrm{ft}(0.6 \mathrm{~m})$ were loaded. These short holes were caused by water filling the initial holes which turned the sandy clay and silt to a soupy mixture, making excavation practically impossible. The holes which were less than required depth at site III were 5 to $6 \mathrm{ft}(1.5$ to $1.8 \mathrm{~m})$ deep.

\section{CONCLUSIONS}

10. Athough the Raystown project was not conceived for the purpose of investigating emplacement-hole formation using shaped charges, some significant observations were made in the course of execution:

a. The success of using shaped charges to create emplacement holes depends on the soil types present. Good initial penetration is achieved in almost all cases, but one's ability to clean out the hole is limited. In rocky soil the standard posthole digger works well, but is limited to a $5-\mathrm{ft}(1.5-\mathrm{m})$ depth; the hand auger has difficulty in excavating where rocks in the hole, or those penetrating from the hole wall, exceed 2 to 3 in. ( 50 to $75 \mathrm{~m}$ ).

$b$. A road with a well prepared base makes hole excavation more difficult. The tendency of the larger base course material to fall into the hole makes excavation below $5 \mathrm{ft}(1.5 \mathrm{~m})$ very difficult; water-filled holes in material that becomes soupy when saturated are practically impossible to excavate.

c. Standoffs can be easily constructed out of many different materials and should be used to insure maximum penetration and minimum surface disruption. 
Table A1

Results of Shaped Charges Used to Form Emplacement Holes

\begin{tabular}{|c|c|c|c|c|c|c|c|c|c|c|}
\hline \multirow[b]{2}{*}{ Site } & \multicolumn{2}{|c|}{$\begin{array}{c}\text { Required } \\
\text { Depth } \\
\end{array}$} & \multirow{2}{*}{$\begin{array}{l}\text { Number } \\
\text { of Holes }\end{array}$} & \multicolumn{2}{|c|}{$\begin{array}{l}\text { Average } \\
\text { Initial } \\
\text { Depth } \\
\end{array}$} & \multirow{2}{*}{$\begin{array}{l}\text { Number } \\
\text { Dug to } \\
\text { Required } \\
\text { Depth }\end{array}$} & \multirow{2}{*}{$\begin{array}{l}\text { Number } \\
\text { Dug to } \\
\text { Less Than } \\
\text { Required } \\
\text { Depth } \\
\end{array}$} & \multicolumn{2}{|c|}{$\begin{array}{c}\text { Average } \\
\text { Depth of } \\
\text { Short } \\
\text { Holes } \\
\end{array}$} & \multirow{2}{*}{$\begin{array}{l}\text { Percent } \\
\text { Dug to } \\
\text { Required } \\
\text { Depth }\end{array}$} \\
\hline & It & $\underline{m}$ & & $\mathrm{ft}$ & $\underline{m}$ & & & $\mathrm{ft}$ & $\overline{\mathbf{m}}$ & \\
\hline \multicolumn{11}{|c|}{ Vertical Holes } \\
\hline I & 5 & 1.5 & 11 & 3.88 & 1.18 & 11 & -- & - & - & 100.0 \\
\hline I & 7 & 2.1 & 34 & 3.88 & 1.18 & 16 & 18 & 6.33 & 1.93 & 47.0 \\
\hline II & 5 & 1.5 & 6 & 3.47 & 1.05 & 6 & -- & - & - & 100.0 \\
\hline II & 7 & 2.1 & 17 & 3.47 & 1.05 & 12 & 5 & 6.65 & 2.03 & 70.6 \\
\hline III & 5 & 1.5 & 2 & 2.54 & 0.77 & 0 & 2 & 3.0 & 0.91 & 0.0 \\
\hline III & 7 & 2.1 & 15 & 2.54 & 0.77 & 5 & 10 & 4.49 & 1.37 & 33.3 \\
\hline \multicolumn{11}{|c|}{ Slant Holes } \\
\hline I & 7 & 2.1 & 6 & 4.62 & 1.41 & 5 & 1 & 5.7 & 1.74 & 83.3 \\
\hline II & 7 & 2.1 & 3 & 3.8 & 1.16 & 2 & 1 & 6.8 & 2.07 & 66.7 \\
\hline
\end{tabular}




\section{APPENDIX B: SELECTED CRATER PROFILES}

1. This appendix contains selected crater profiles for each of the three sites. The first three figures (B1-B3) are from site I. They show the effectiveness of the three-hole design (B2 and B3) as compared with the standard deliberate road crater (B1). Figure B4 shows site II where the craters were detonated parallel to the roadway. Figures B5-B8 show site III. Figures B5 and B6 show craters detonated prior to the flooding of the adjacent countryside, and Figures B7 and B8 show the larger craters produced once the rising waters had begun inundating the adjacent countryside. Elevations on these figures are arbitrary and are not referenced to mean sea level. The ordinate and abscissa scales are in feet.
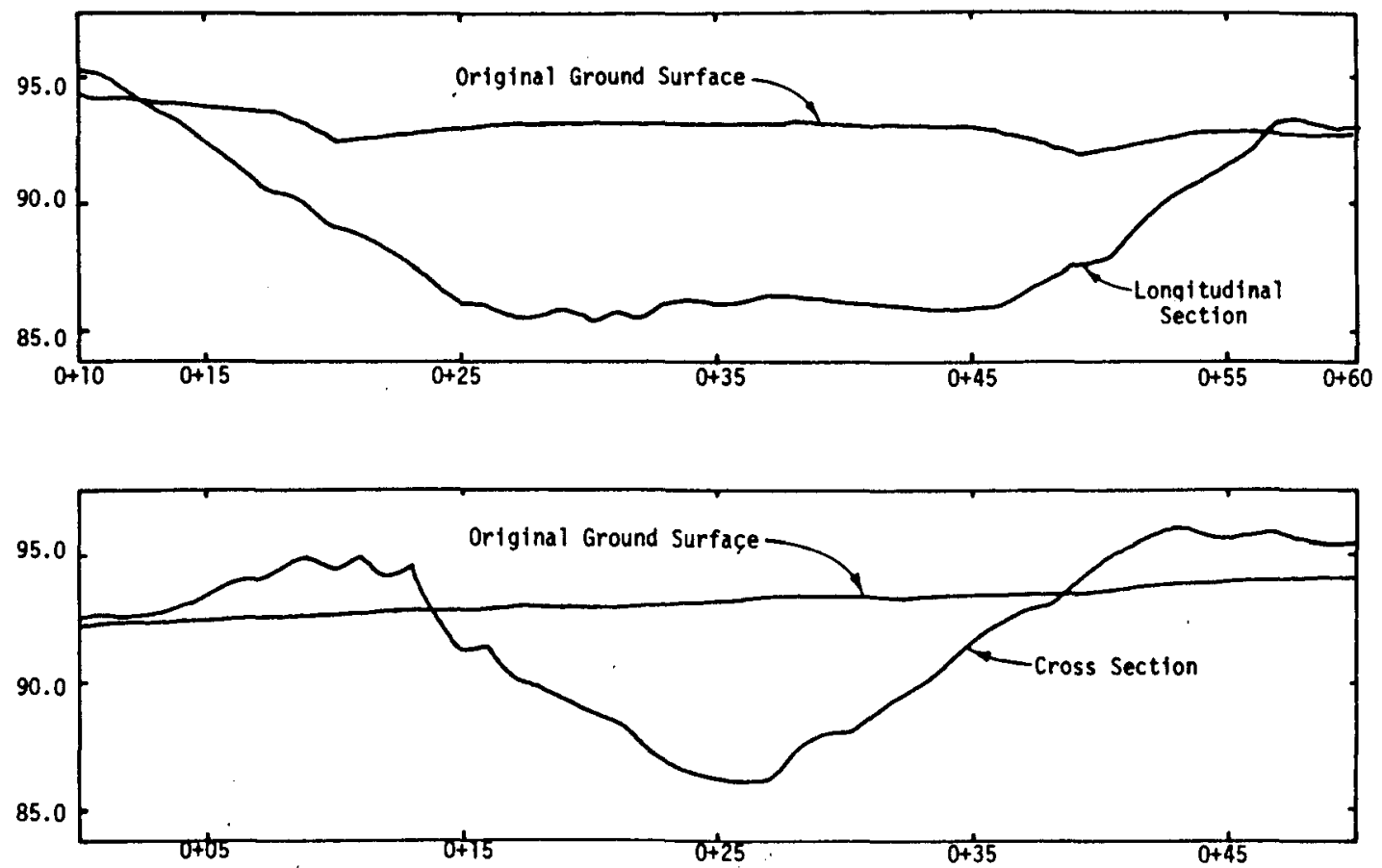

Figure Bt. Dêsign A'T îred'at'sitel 

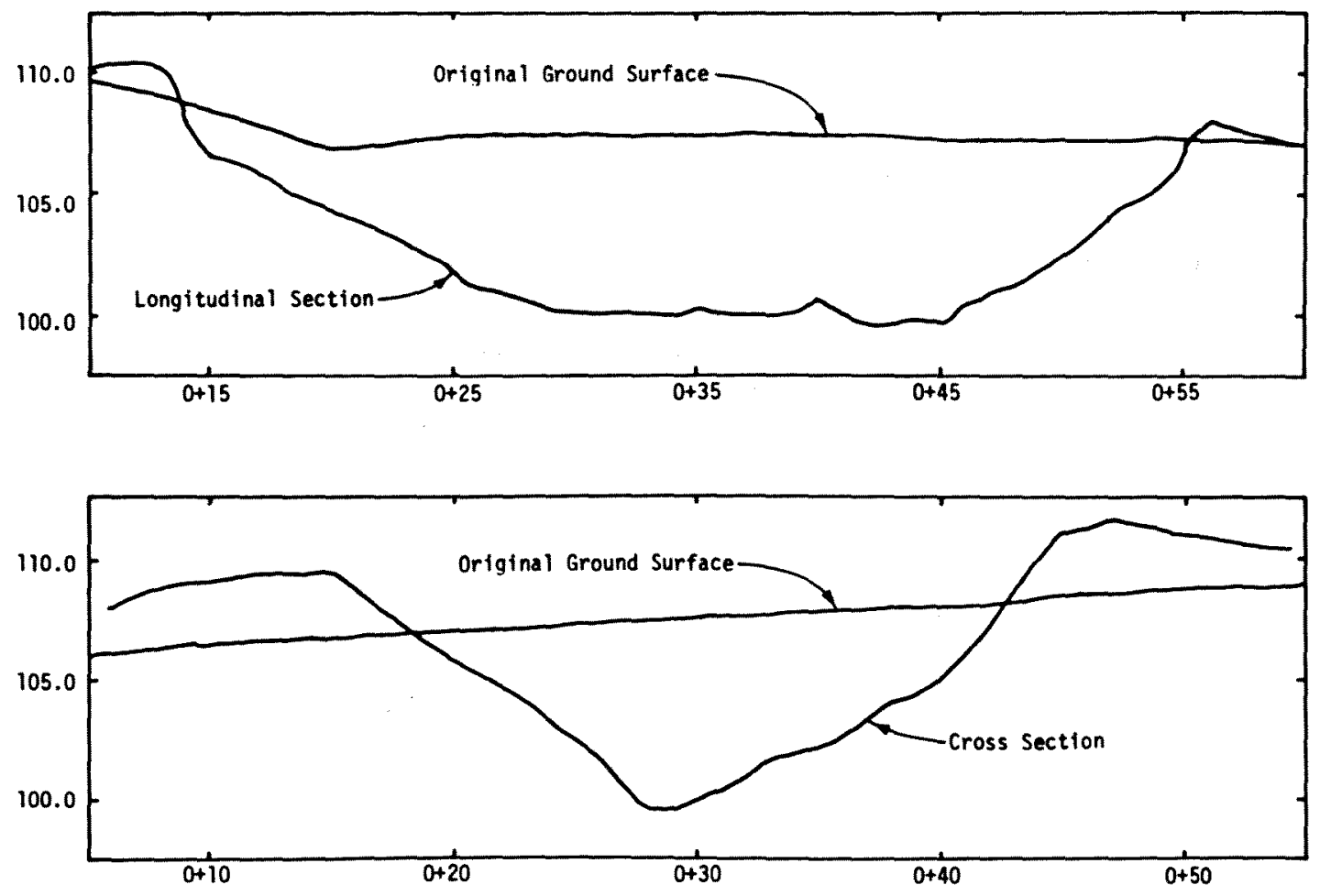

Figure B2. Design C1 fired at site I
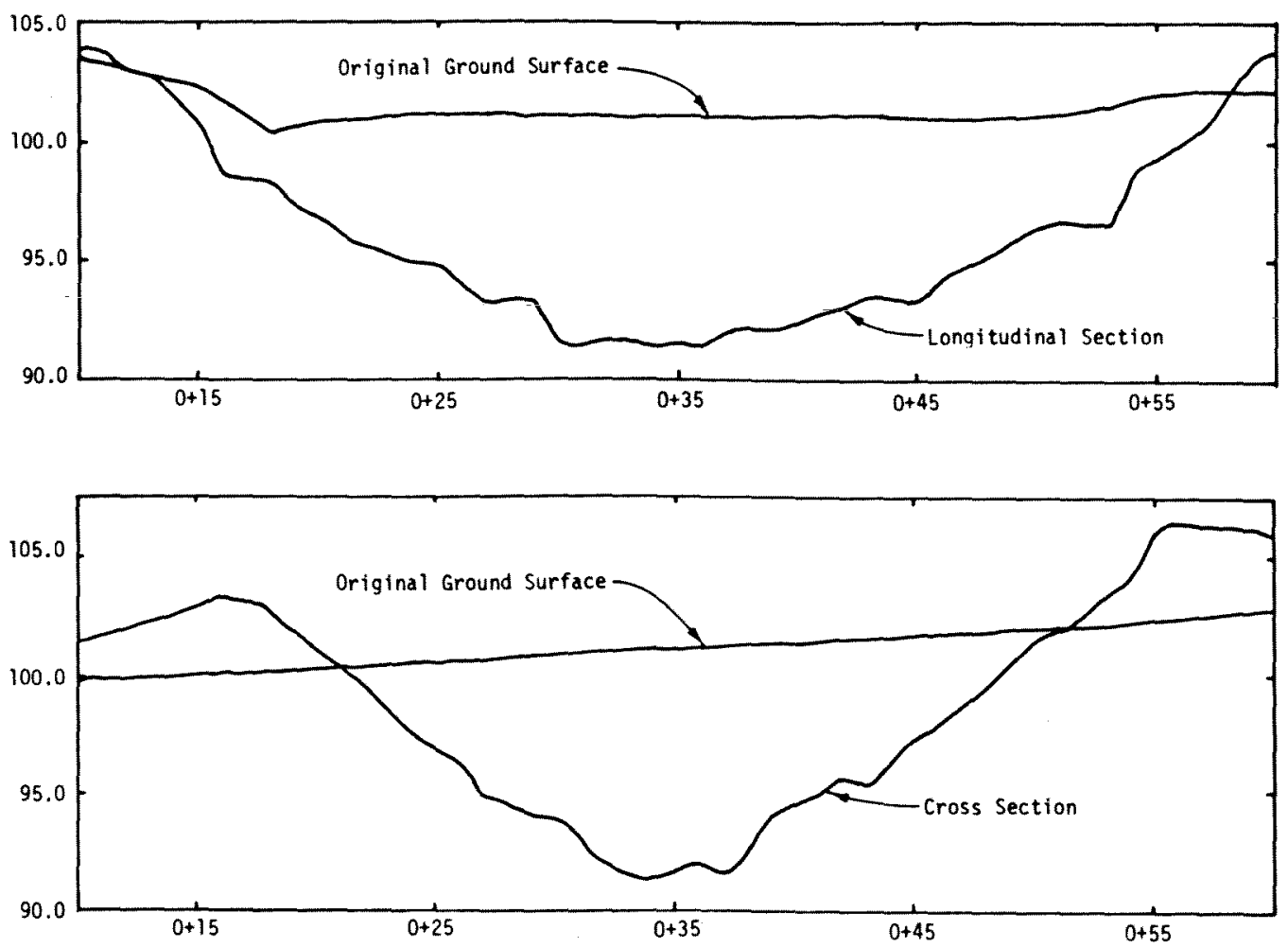

Figure B3. Design D1 fired at site I 

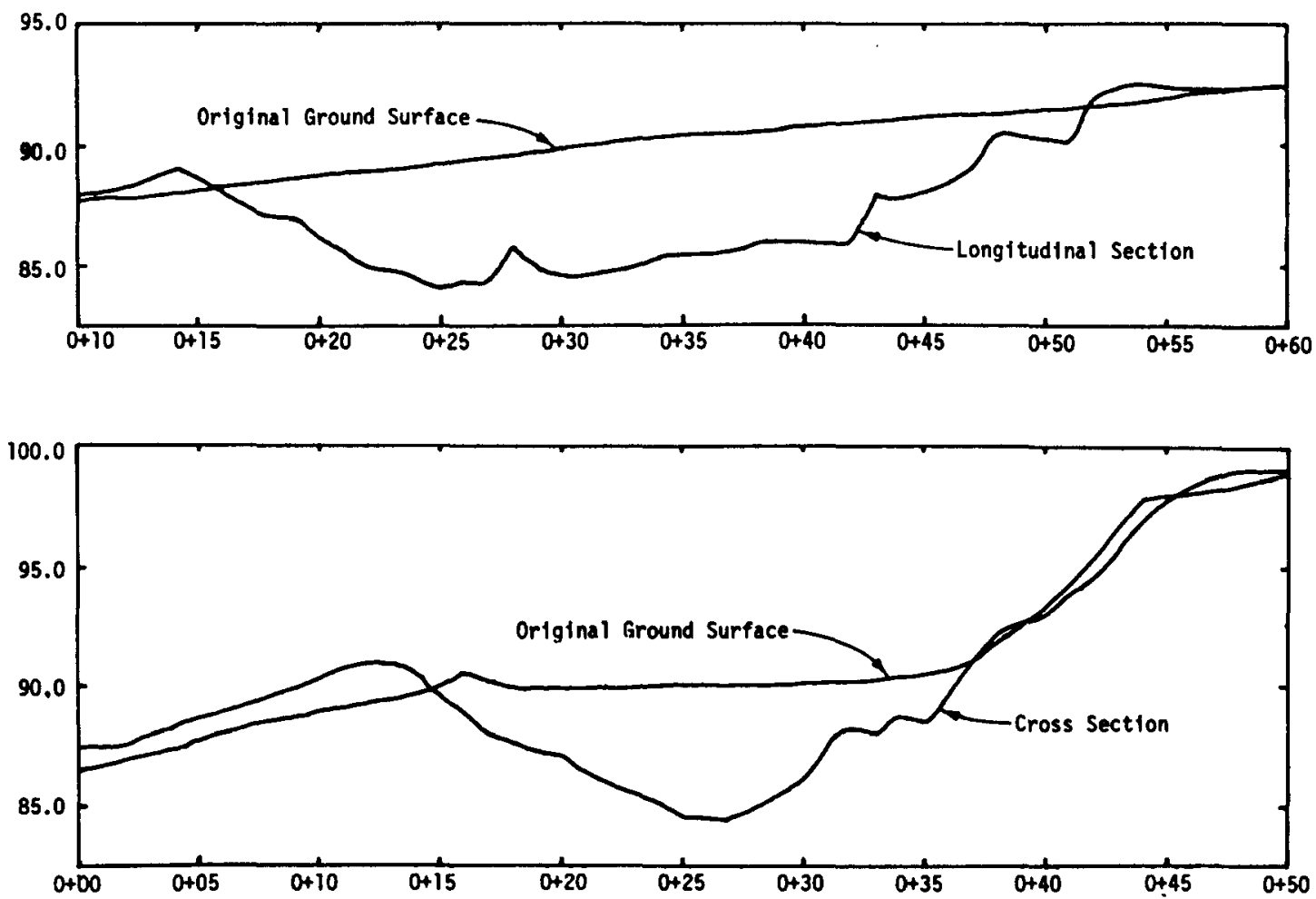

Figure B4. Design F3 fired at site II parallel to road
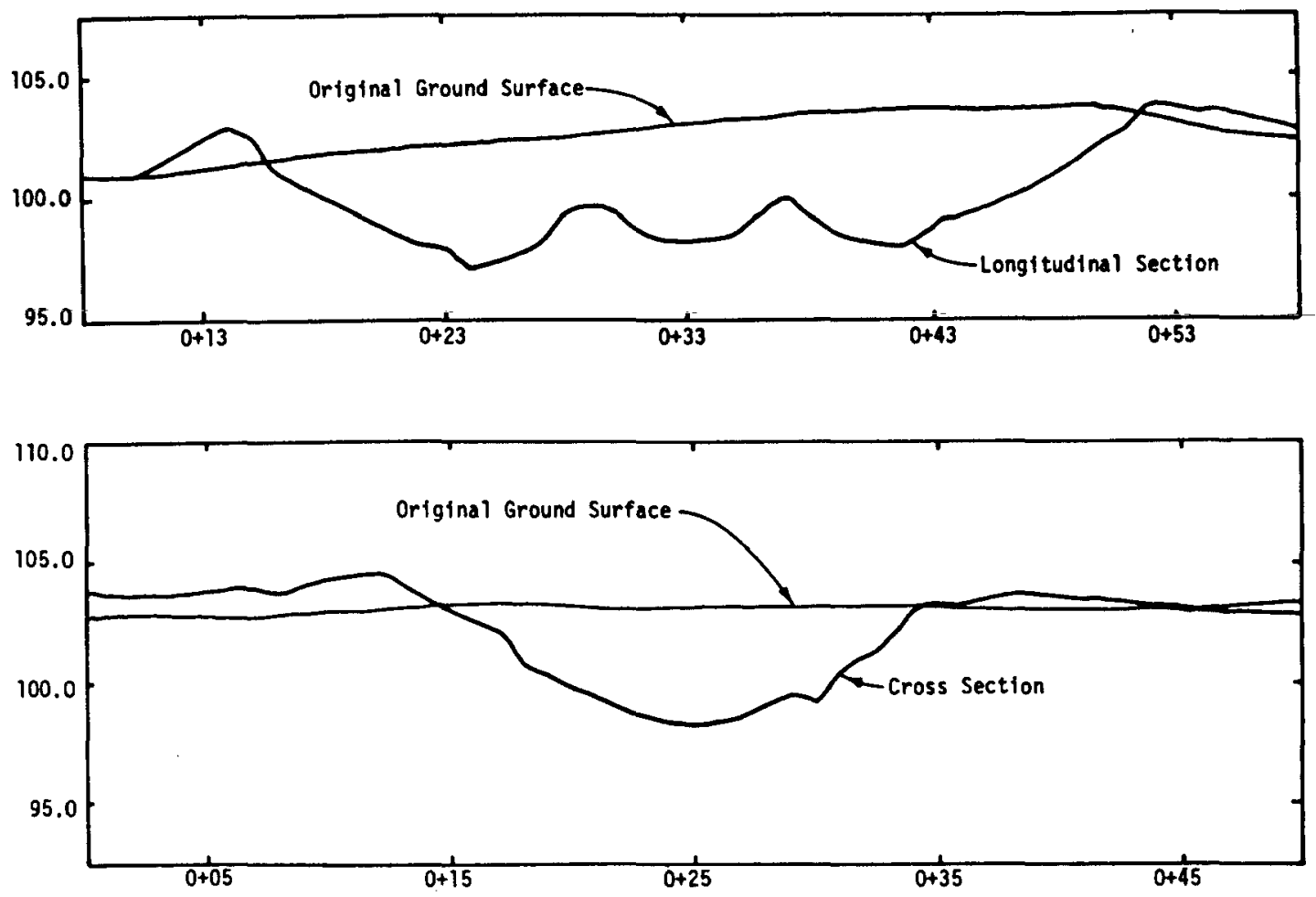

Figure B5. Design E1 fired at site III 

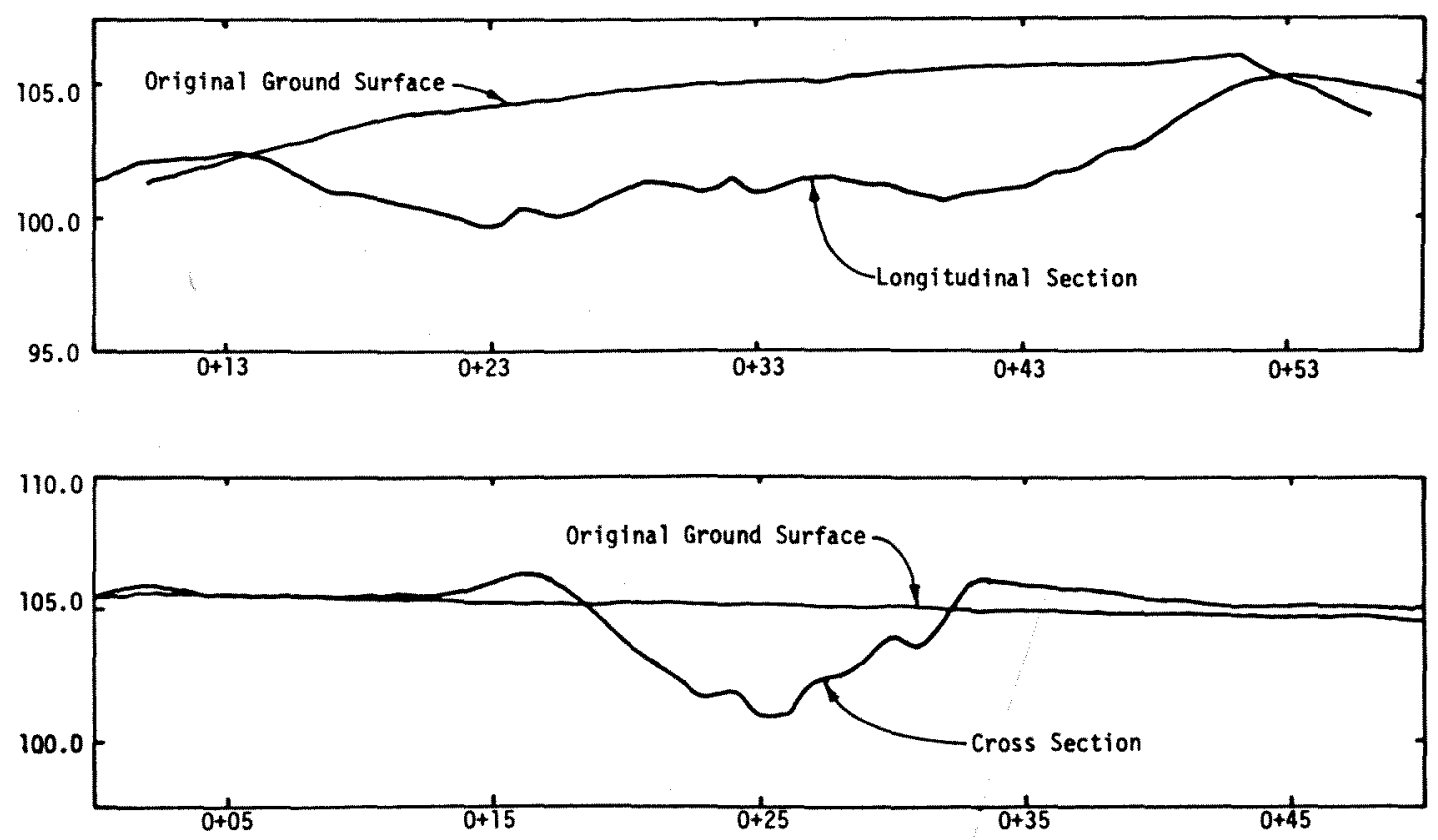

Figure B6. Design F1 fired at site III
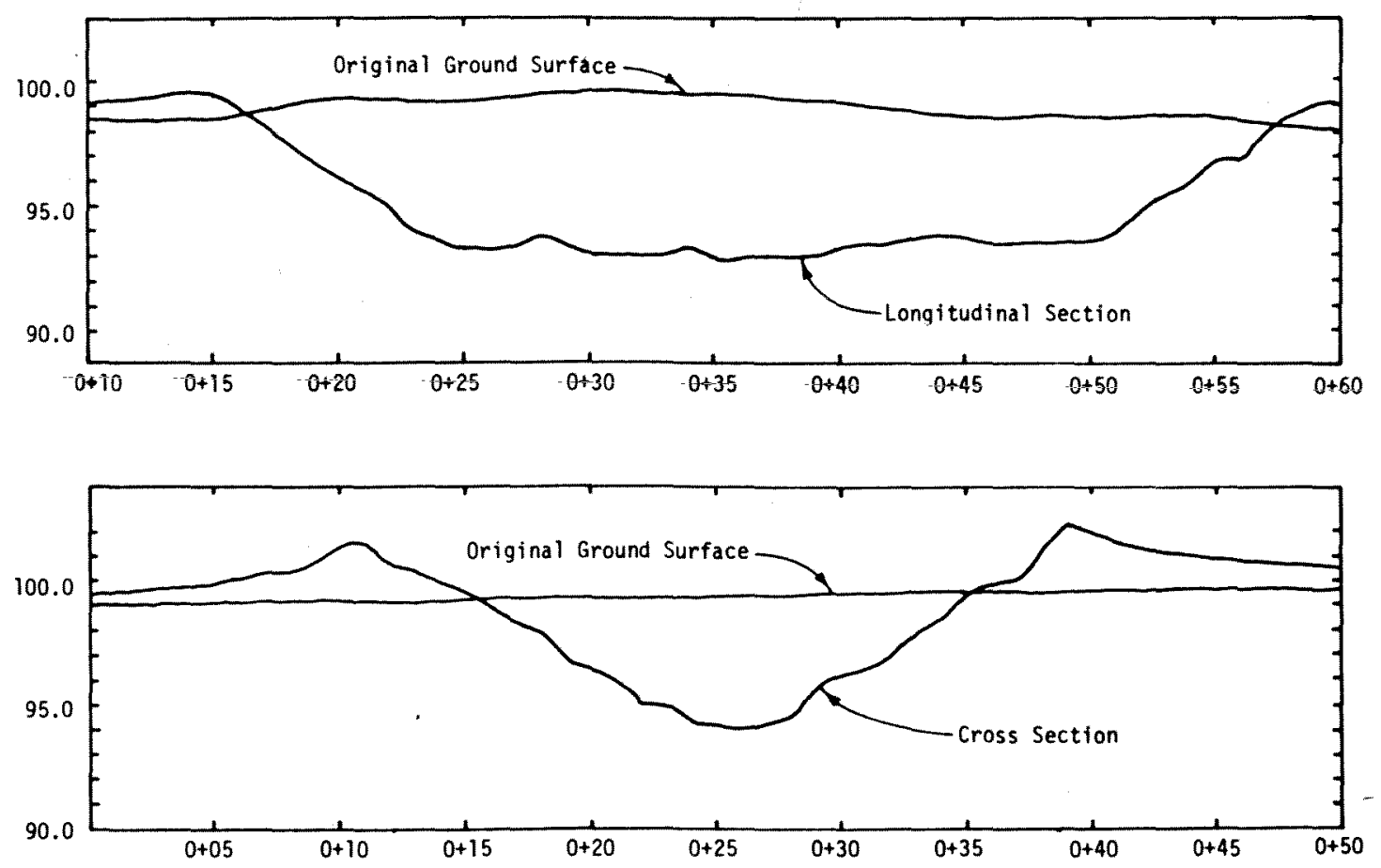

Figure B7. Design B3 fired at site III 

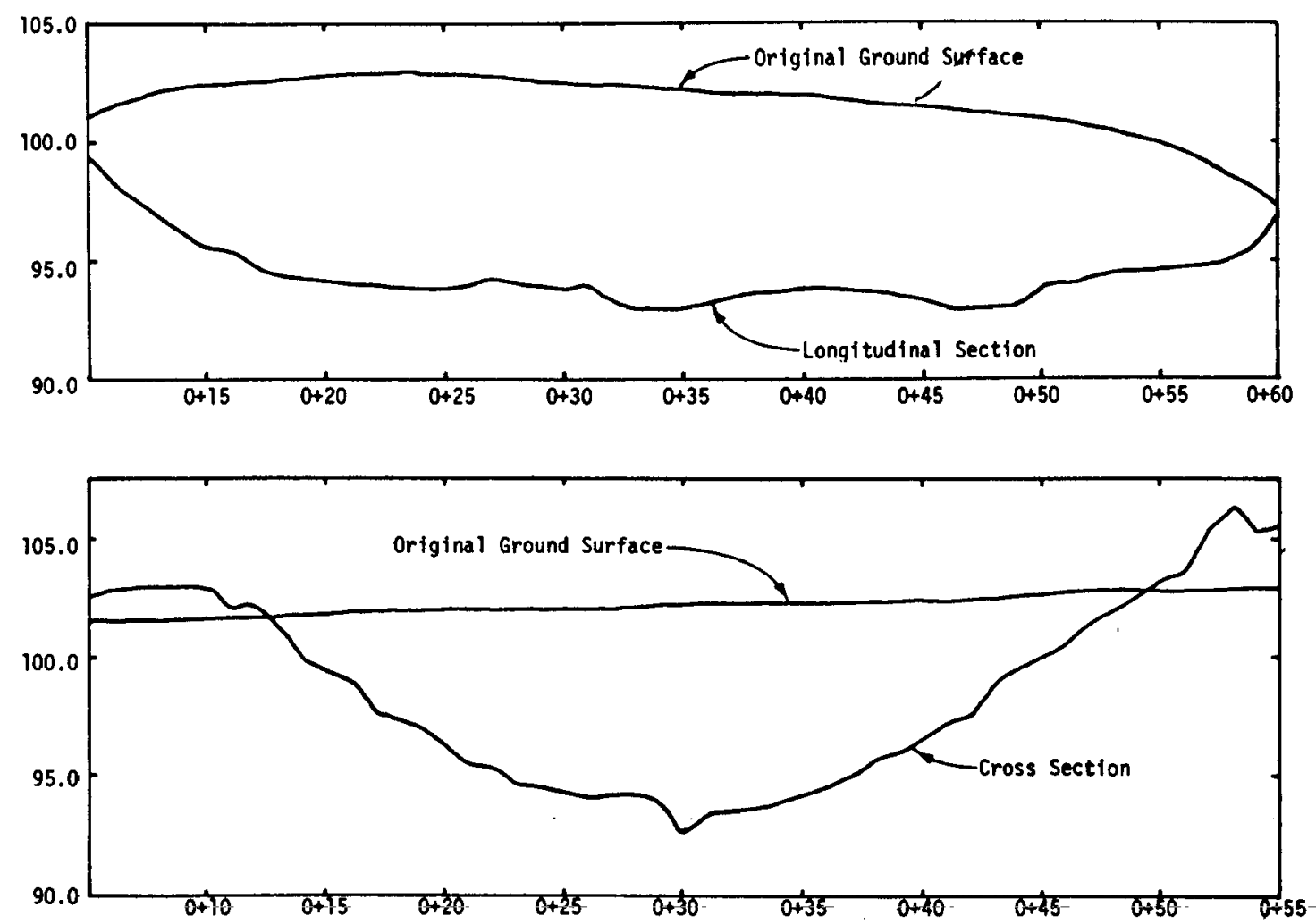

Figure B8. Design D3 fired at site III 


\section{APPENDIX C: RELIEVED-FACE CRATERS}

\section{INTRODUCTION}

1. The relieved-face road crater is designed to be a more effective obstacle to modern tanks than the standard V-shaped craters. The technique is designed to produce a trapezoidal-shaped crater with a steeper slope on the "friendly" side by firing two rows of charges with a delay between them. The row nearest the enemy is fired first and the second row is fired after a 1/2-to 1-1/2-sec delay. The standard design calls for charges of 30 and $40 \mathrm{lb}(14$ and $18 \mathrm{~kg}$ ) buried at 4- and 5-ft (1.2- and $1.5-\mathrm{m})$ depth.* Our design was an improved version of the standard design. This appendix describes the three relieved-face craters attempted during Project RAYSTOWN.

\section{RESULTS}

2. The normal procedures used in all the other cratering work were also used for design $\mathrm{H}$, the relieved-face experiments, except that two ring-mains were used, one for each row. The delayed row of charges failed to detonate on all three shots. On two of the three shots this appeared to be due to the design and delay period. On the third shot, the misfire was caused by faulty firing wire. The films of the first shot indicate that the detonation of the first row disrupted the second row's ring-main.

3. It was possible to dig out the emplacement holes of the second row of charges, find the torn ends of the detonating cord down lines, and refire the charges successfully. Because of the problems encountered with this design, and the dependence of the design's success on detonating the second shot while material from the first is still airborne, no crater measurements were taken.

\section{CONCLUSION}

4. The failure of design $\mathrm{H}$ to work properly is directly related to two things. Either the time delay between rows was too great or the rows were spaced too closely together. Possibly a combination of these two things was the main reason the design failed. Despite the problems encountered with this design, it did demonstrate the insensitivity of the military slurry (with booster) to nearby explosions, and also that these nearby explosions had no apparent effect on the subsequent detonation of the remaining slurry.

5. The time delay between rows should be shortened to avoid the detonating cord ring-main being cut off from the down lines. Presently, a 1-msec delay capability does not exist with the caps available in the inventory. With the 1-sec time delay it appears that there is a strong possibility that material ejected by detonation of the first row will adversely affect the firing system (ring-main) used for the second row. In effect, the crater from the first row includes the top several feet of the second row and, if it has time enough to develop, it appears it can rip the detonating cord ring-main away from the charges. It would seem that it should be possible to increase the width between rows to preclude this problem.

6. It appears that more work is required to resolve the problems encountered with relieved-face cratering. The concept is a good one, but the execution in various media and with slightly expanded designs was unsuccessful.

* Office, Chief of Engineers, Department of the Army, "Explosives and Demolitions," Field Manual FM 5-25, Feb 1971, Washington, D. C. 
In accordance w1th IRR 70-2-3, paragraph $6 c(1)(b)$, dated 15 February 1973, a facB imile catalog card in Library of Congress format is reproduced below.

Reed, Howard $\mathrm{H}$

Deliberate road crater design test series:

Raystown, Pennsylvanla, by Howard H. Reed. Vicksburg,

U. S. Army Engineer Waterways Experiment Station, 1976.

$1 \mathrm{v}$. (various pagings) 1llus. $27 \mathrm{~cm}$. (U. S.

Waterways Experiment Station. Miscellaneous paper $\mathrm{N}-76-6)$

Prepared for Office, Chief of Engineers, U. S. Army, Washington, D, C.

Bibliographical footnotes.

1. Cratering. 2. Explosive charges. 3. Road craters. 4. Slurry explosive. I. U. S. Army. Corps of Engineers. (Series: U. S. Waterways Experiment Station, Vicksburg, Miss. Miscellaneous paper N-76-6) TA7.W34m no. N-76-6 